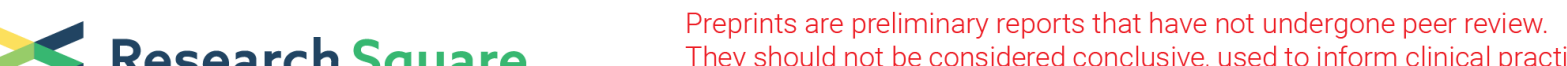 $\begin{array}{ll}\text { Research Square } & \text { They should not be considered conclusive, used to inform clinical practice, } \\ \text { or referenced by the media as validated information. }\end{array}$
}

\section{Factors in multiple behaviour change interventions affecting smoking cessation success: a rapid realist review.}

Nadia Minian

Centre for Addiction and Mental Health

Tricia Corrin

Centre for Addiction and Mental Health

Mathangee Lingam

Centre for Addiction and Mental Health

Wayne K deRuiter

Centre for Addiction and Mental Health

Terri Rodak

Centre for Addiction and Mental Health

Valerie H. Taylor

University of Calgary

Heather Manson

Public Health Ontario

Rosa Dragonetti

Centre for Addiction and Mental Health

Laurie Zawertailo

Centre for Addiction and Mental Health

Osnat C. Melamed

Centre for Addiction and Mental Health

Margaret Hahn

Centre for Addiction and Mental Health

Peter Selby ( $\sim$ peter.selby@camh.ca )

Centre for Addiction and Mental Health https://orcid.org/0000-0001-5401-2996

Research article

Keywords: realist review, multiple health behaviour interventions, smoking cessation, COM-B

Posted Date: March 3rd, 2020

DOI: https://doi.org/10.21203/rs.3.rs-15687/v1 
License: (c) (1) This work is licensed under a Creative Commons Attribution 4.0 International License. Read Full License

Version of Record: A version of this preprint was published at BMC Public Health on June 12th, 2020. See the published version at https://doi.org/10.1186/s12889-020-08973-2. 


\section{Abstract}

Background Smoking continues to be a leading cause of preventable chronic disease-related morbidity and mortality, excess healthcare expenditure, and lost work productivity. Tobacco users are disproportionately more likely to be engaging in other modifiable risk behaviours such as excess alcohol consumption, physical inactivity, and poor diet. While hundreds of interventions addressing the clustering of smoking and other modifiable risk behaviours have been conducted worldwide, there is insufficient information available about what components of these interventions help to promote successful smoking cessation. The aim of this rapid realist review was to identify possible mechanisms used in multiple health behaviour change interventions (targeting tobacco and two or more additional risk behaviours) that are associated with effectively changing tobacco use.

Methods This realist review method incorporated the following steps: (1) clarifying the scope, (2) searching for relevant evidence, (3) relevance confirmation, data extraction, and quality assessment, (4) data analysis and synthesis.

Results Of the 20,423 articles screened, 138 articles were included in this realist review. Following Michie et al.'s behavior change model (the COM-B model), capability, opportunity, and motivation were used to identify the mechanisms of behaviour change. Universally, increasing opportunities (i.e. factors that lie outside the individual that prompt the behaviour or make it possible) for participants to engage in healthy behaviours was associated with smoking cessation success. However, increasing participant's capability or motivation to make a behaviour change was only successful within certain contexts.

Conclusion In order to address multiple health behaviours and assist individuals in quitting smoking, public health promotion interventions need to shift away from 'individualistic epidemiology' and invest resources into modifying factors that exist outside of the individual (i.e. creating a supportive environment). Study registration PROSPERO registration number: CRD42017064430

\section{Background}

Smoking continues to be a leading cause of preventable chronic disease-related morbidity and mortality, excess healthcare expenditure, and lost work productivity [1-5]. While tobacco control efforts have made significant strides in reducing the overall prevalence of smoking in North America, millions of individuals report smoking in 2018 [6-8]. Furthermore, disparities in smoking remain prevalent across population groups [6].

Tobacco users are disproportionately more likely to be engaging in other modifiable risk behaviours such as excess alcohol consumption, physical inactivity, and poor diet [9]. A recent review identified strong associations between tobacco use and other modifiable risk behaviours [9], supporting an earlier report that only $12 \%$ of smokers had no other modifiable risk behaviours [10]. Tobacco users tend to consume more alcohol, eat less fruits and vegetables, and engage in fewer leisure time physical activity compared to non-tobacco users [11]. The clustering of these modifiable risk behaviours among tobacco users 
translates to a heightened risk for cardiovascular disease [12] and other chronic diseases may also negatively influence the likelihood of successful smoking cessation [13-17].

Methods to improve cessation rates are of utmost importance as the percentage of tobacco users who are able to quit and maintain abstinence unaided is low, estimated at $3-5 \%$ annually [18]. Identifying and implementing smoking cessation interventions that are holistic and address other modifiable risk behaviours may improve quit outcomes and enhance overall quality of life. A Cochrane review of interventions that targeted multiple modifiable risk behaviours (including smoking) estimated a net reduction in smoking prevalence of $24 \%$ [19]. However, older guidelines for smoking cessation traditionally recommended only focusing on smoking cessation [20-23].

While hundreds of interventions addressing the clustering of smoking and other modifiable risk behaviours have been conducted worldwide [12, 24-28], there is insufficient information available about what components of these interventions help to promote successful smoking cessation [19]. A rapid realist review, which emphasizes the mechanisms within the intervention that contribute to the outcomes and the context, can provide a more in-depth understanding of how and why interventions are successful or unsuccessful $[29,30]$.

As a result, a rapid realist review was undertaken to analyze and characterize the various components of multiple health behaviour change interventions that contribute to the successful smoking cessation. The mechanisms within interventions were characterized using the Capability, Opportunity, and Motivation Model of Behaviour (COM-B model), which states that an individual's behaviour (B) is part of an interacting system involving 3 conditions: capability (C), opportunity (O), and motivation (M) [31]. COM-B is located at the centre of the Behaviour Change Wheel; which provides recommendations for types of interventions functions to use to address each component of COM-B [31]. COM-B can also be mapped to the Behaviour Change Technique (BCT) Taxonomy; which provides a systematic approach for designing interventions [31, 32]. The COM-B model, therefore, provides the foundation and starting point for intervention development.

The information gathered from this rapid realist review is intended to guide the curriculum and program development for Picking up the PACE (Promoting and Accelerating Change through Empowerment), a project funded by the Public Health Agency of Canada and the Medical Psychiatry Alliance. Picking Up the PACE aims to increase the capacity of practitioners to address other modifiable risk behaviours (e.g. physical inactivity, excessive alcohol use and poor diet) as a part of smoking cessation treatment. Picking Up the PACE aims to improve practitioner's capacity to address multiple health behaviours through two essential components: 1) developing an online training curriculum for healthcare practitioner outlining strategies and techniques for addressing multiple modifiable risk behaviours as a part of smoking cessation treatment and 2) designing a just-in-time clinical decision support system that will guide practitioners to address the engagement of multiple risk behaviours by their patients. The findings from this rapid realist review will also provide transferrable learnings for practitioners and decisionmakers who are trying to develop multiple health behaviour change interventions. 
In this paper, we report the findings of a rapid realist review of the current literature to produce a nuanced and critical understanding of the circumstances in which interventions for multiple modifiable risk behaviours increase smoking cessation outcomes. Specifically, the aim of this rapid realist review was to identify possible mechanisms used in multiple health behaviour change interventions (targeting tobacco and two or more additional risk behaviours) that are associated with effectively changing tobacco use.

\section{Methods}

\section{Rationale for a Rapid Realist Review}

Traditional approaches to literature reviews (systematic reviews and meta-analyses) assume outcomes are generated by linear causation [33]. While these approaches work well for studies conducted with highly controlled settings and exposures (e.g. randomized control trials); they severely limit our understanding of complex and pragmatic interventions [34]. Complex and pragmatic interventions require methods that offer a more comprehensive explanation of 'process' that was undertaken [35]. Therefore, a realist synthesis is well-suited to meet these needs as it is able to synthesize complex evidence from diverse sources to provide an understanding of what works in and intervention and how.

Specifically, a realist synthesis is a theory-driven approach for reviewing research evidence on complex interventions $[29,30]$. Its aim is to understand how, for whom, where, and why the intervention is effective or ineffective. This is accomplished by examining the "mechanisms"(M) (program theory), exploring the "contexts" (C) where the intervention occurred, and then linking these contexts and mechanisms to the "outcome" of the intervention (0) [29]. This is called a C-M-O configuration. Recurrent patterns of C-M-O configurations are known as demi-regularities, or semi predictable pattern or pathway of how a program functions. In other words, demi-regularities are a broad rule for how and when certain outcomes usually occur [29].

While full realist reviews can require a considerable time dedicated to the exploration of literature and subsequent analysis, rapid realist reviews (RRRs) have been used to enable a quicker transition from research to policy and/or practice [36]. Given the need for a timely synthesis and its application for the Picking Up the PACE programme, we undertook a rapid realist review; which allows us to maintain the core elements of the realist methodology and produce timely data.

Prior to this rapid realist review, a pre-specified protocol was registered (PROSPERO registration number: CRD42017064430) and published [37] which included the research question, search strategy, synthesis methodology, preliminary program theory, definitions, inclusion criteria for relevance screening, data extraction form, quality assessment tool, and plans for dissemination. An overview of the methods and any modifications to the original protocol are described below. Utilizing the RAMESES (Realist and Meta-narrative Evidence Syntheses: Evolving Standards) [38], and adapting it to follow a rapid realist review [35], the following steps were applied:

\section{Clarifying the Scope}


Identifying the research question. This rapid realist review supports a larger program, Picking Up the PACE, that aims to increase the ability of healthcare providers to offer evidence-based interventions to tobacco users which encompass changing modifiable risk behaviours (excess alcohol consumption, physical inactivity, poor diet, stress, and poor sleep) to ultimately achieve long-term smoking abstinence. As a result, these six risk behaviours are the focus of this review.

In order to clarify the scope of the rapid realist review, a multidisciplinary team with expertise in knowledge synthesis, public health, and multiple health behaviour change met in-person on nine occasions for 1 hour over the course of six months. Our initial research question was: "What factors are associated with effective multiple health behaviour change (three or more behaviours including smoking)?"

Changes in the rapid realist review process. After a preliminary review of the data, further specificity of the study question was required to meet the desired outcome. Mechanisms involved in changing multiple health behaviours might be different than those involved in smoking cessation. Thus we modified our research question to: "What factors are associated with effectively changing tobacco use that target two or more additional unhealthy behaviours."

Initial theory. We identified our initial theory of how, when, and why multiple health behaviour change interventions work by reviewing seven large-scale multi-factorial cardiovascular disease and cancer risk interventions [39-45]. These studies included Multiple Risk Factor Intervention Trial (MRFIT) [39], the North Karelia Project [40], Stanford Five City Project [41], Project PREVENT [43], Minnesota Heart Health Program [45], Mediterranean Lifestyle Trial [44], and the BETTER Trial [42], all of which are well-known studies that promoted multiple health behaviour change in large community samples [46]. As specified in our protocol manuscript [37], our preliminary review of these seven interventions involved having two independent reviewers extract the following information from the studies:

1. The specific activities within each intervention. Activities are physical/tangible tasks that were undertaken by the intervention (e.g. , counselling, sharing of educational flyers, workshop, courses, prize draw).

2. The setting in which the intervention took place, including physical environment, social setting, and political climate (if provided).

3. The outcomes of each intervention, including any behavioural and/or clinical outcomes.

Through this preliminary review, we found two contextual factors that were common among successful interventions: pre-existing infrastructure that facilitates the delivery of the intervention, and targeting regions (e.g. geographic, population groups) where the need for the intervention is well-characterized. Furthermore, activities undertaken by these interventions often targeted the surrounding community and/or organizational structure. This multi-level approach appears to be in an effort to change the physical and social opportunities that can help facilitate multiple health behaviour change in individuals. 
Individual-level activities frequently focused on increasing patient's awareness and knowledge, improving feelings of support, empowerment, and incorporating incentives for completing activities.

Upon closer review, we realized that these activities mapped onto the COM-B model; which stipulates that behaviour change requires change in one or more of the following conditions: capability, opportunity, and motivation [31]. All seven studies used in developing our initial program theory sought to change at least one component of this behavioural system. We used the taxonomy of behaviour change techniques [32] to code each activity specified in the studies and we cross-referenced these codes with the COM-B model. We used Table 2 in the Michie and colleagues article to help us create the links between the components of the COM-B model and the BCT taxonomy [31]. For example an intervention that helped participants set a quit date was categorized as BCT 1.3"Goal setting" consequently coded under "Capability" within the COM-B model. A visual depiction of this theory can be found in the published protocol [37].

The coded data was reviewed by our expert panel, which had a total of 11 members and was comprised of representatives from the Medical Psychiatry Alliance, Public Health Ontario, and the Centre for Addiction and Mental Health. Over the course of 9 in-person meetings, the expert panel assisted the research team with the review and development the initial program theory.

Searching for Relevant Evidence: Search Strategy and Eligibility Criteria

To test our program theory, a search strategy was developed and implemented to retrieve relevant primary data from both academic and grey literature. The search strategy was informed by the research team and developed by a medical librarian who executed the search across multiple bibliographic databases [37]. After our protocol was published, minor changes were made to the search strategy (see Additional File 1 for the final version). The initial search aimed to identify as many multiple health behaviour interventions as possible, allowing the team to accurately identify trends across the literature.

To identify grey literature from Canada, Europe, and the USA, variations of the phrase "multiple health behaviours" were used to hand search the websites and online repositories of international, national, and provincial health organizations, health behaviour/condition-specific associations, clinical trial registries, and grey literature repositories. Reference lists of three systematic reviews and meta-analyses $[28,47,48]$ were also hand searched to identify any relevant resources not captured by the systematic searches. No additional articles were included from the grey literature or reference list searches. After the search was complete, we chose to exclude books and reviews. It should be noted that 22 interventions were identified as having more than one publication reporting similar results. In these cases, the lead scientist and two additional members of the team selected one article per intervention to represent the mechanisms and outcomes of the intervention, and excluded other articles associated with that intervention.

Relevance Confirmation, Data Extraction, and Quality Assessment

Two independent reviewers assessed each study to determine its relevance to our research question, extract pertinent information, and appraise its quality using pre-designed and pre-tested relevance 
screening and data extraction forms [37]. The systematic review software DistillerSR [49] was used for this process. As described in our protocol [37], to be included in this review the study had to:

Describe interventions that targeted tobacco use as well as two or additional modifiable risk behaviours (excess alcohol consumption, physical inactivity, poor diet, stress, and poor sleep).

Report on long-term (5 months or longer) smoking cessation outcomes

Since we had multiple study designs included in this rapid realist review, a combination of the Mixed Methods Appraisal Tool (MMAT) [50] and the Critical Appraisal Skills Programme (CASP) [51] was used to evaluate the methodological quality of qualitative, quantitative, and mixed method studies. Each type of study was assessed by two reviewers using a pre-designed quality assessment form [37]. As per MMAT and CASP appraisal methods, the quality criteria differed based on the study design; quantitative - randomized controlled trial (eight criteria), quantitative - non-randomized (10 criteria), qualitative (10 criteria), and mixed-method (six criteria). These criteria were scored using a nominal scale (Yes/No/Can't Tell).

Based on the scoring metrics of the MMAT [50] and adjusting for the additional CASP criteria [51], an overall quality score was calculated for each study using the descriptors $*, \star \star, * \star \star$, and $\star \star \star \star$. For all types of studies, the score was derived by taking the number of criteria met and dividing it by the number of

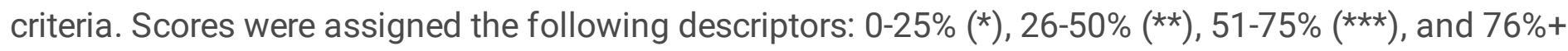
$(\star \star \star \star)$. To score the mixed methods studies, the overall quality could not exceed the quality of the weakest component of the study. For example, in a mixed method study, if the qualitative score is (**), and the quantitative and mixed method scores are both $(\star \star \star)$, the study is assigned an overall score of the lowest component $\left.{ }^{* *}\right)$.The questions used to score the studies can be found in Additional File 2.

Prior to data extraction and coding of the context, mechanisms, and outcomes within the studies, reviewers were trained on the COM-B model, the Behaviour Change Wheel and the BCT taxonomy [31, 32]. They were also trained on how characterize the various techniques that are used within interventions and map these to COM-B model. Once trained, the following process was also undertaken by the two independent reviewers:

Review article to identify and record the activities that took place in the intervention.

Code the health behaviours the intervention was targeting.

Code which techniques were applied to each activity, as defined by the BCT taxonomy.

Determine how each technique is associated with the COM-B model.

Code the target population (e.g. gender, ethnicity, general public vs patients)

Code the smoking outcome(s), including whether there was a statistically significant change and the follow-up period in which the outcome was assessed (e.g. end of treatment, 6 months, 12, 24 months) 
Code the context where the intervention took place (e.g. region, clinical setting, clinical, communitybased settings, and/or school-based settings)

At each step, discrepancies between two reviewers were resolved by consensus or, when necessary, by a third reviewer.

\section{Data Analysis and Synthesis Process}

The data from DistillerSR [49] was exported to Microsoft Excel for descriptive analysis and analyzed using NVivo 11 [52]. To determine whether the intervention fit the initial program theory and to identify if there were any emerging patterns in the types and combination of C-M-O's configurations used, the reviewers examined the studies to see whether the interventions had also focused on changed physical and social opportunities and/or other behaviour change techniques such as raising awareness, increasing knowledge, and encouraging empowerment.

Smoking cessation outcomes were measured in a variety of ways across articles, including different time points (e.g. at end of treatment, three months, 12 months), duration of abstinence (e.g. 7-day point prevalence abstinence vs last 30 days), and presentation of data (e.g. descriptive vs statistical analyses). These outcomes were verified (e.g. biochemically) or were self-reported. Both types of outcomes are valid [53-55] and therefore were not differentiated in this study. As a result, we organized our findings by whether statistically significant smoking cessation outcomes were observed and whether the outcome was measured long-term (i.e. five months or longer). Within these outcome types, the interventions were organized by the three categories that were then used to identify the mechanisms (capability, opportunity, and motivation) and the context in which the intervention occurred. Many of the reviewed articles did not describe the context in which the intervention was implemented in sufficient detail. Thus we decided to be as broad as possible, and included three different types of categories under context; 1 ) the continent in which the intervention took place, 2) the type of setting (e.g. clinical, workplace) and 3) whether it was a multidisciplinary intervention. We established the following criteria to report demi-regularities:

There were a minimum of three interventions using the specific C-M-O configuration.

Among interventions with a specific C-M-O configuration, either more than $60 \%$ OR less than $40 \%$ of these interventions reported statistically significant increase in smoking cessation.

To present an example of how this process works, if we discover a C-M-O configuration (e.g. Clinical Setting - Capability - Smoking Cessation Outcome) within an intervention, there must be at least two other interventions with this $\mathrm{C}-\mathrm{M}-\mathrm{O}$ configuration to allow for further analysis. In this hypothetical example, if we have total of ten interventions that have 'Clinical Setting-Capability-Smoking Cessation Outcome' configuration, we then have to determine what percentage of these studies reported a statistically significant increase in smoking cessation. In order for this C-M-O configuration to be categorized as a demi-regularity, at least $60 \%$ of these interventions must report a statistically significant increase in smoking cessation outcome long term (5 months or longer. The demi-regularity in this case 
would be that interventions in clinical settings that target capability are more likely to lead to improvement in smoking cessation outcome. Alternatively, if $40 \%$ or less than $40 \%$ of the interventions report a statistically significant increase in smoking cessation outcome, the demi-regularity would be that interventions in clinical settings that target capability are less likely to lead to improvement in smoking cessation outcome.

In this paper, we analyzed demi-regularities in interventions that were rated four stars in our quality rating, used statistical analyses, and reported long-term smoking cessation outcomes ( 5 months or longer). We chose to only include those interventions with a four star rating as they have the least amount of bias. Once a demi-regularity was discovered, studies that had lower quality assessment scores (less than four stars), and/or did not perform statistical analyses were included in our pool for analysis to confirm if the previously observed demi-regularity persisted.

[INSTRUCTION TO JOURNAL: INSERT Table $1 \& 2$ here]

\section{Results}

The flow of information through the rapid realist review process is shown in Figure 1.

Figure 1. PRISMA flow diagram of articles through the rapid realist review process.

${ }^{\text {a }}$ There were a total of seven studies that were pre-identified for theory development; however one of the seven studies was published in 2013; which is within the timeframe for the literature search (2005 2017) and thus counted in this flow diagram as a part of the total number of studies from the literature search.

A descriptive overview of all the interventions is provided in Table 1. Table 2 outlines the contexts, activities, and mechanisms used by interventions with statistically significant long-term (at five months follow-up or longer) smoking cessation outcomes.

\section{[INSTRUCTION TO JOURNAL: INSERT TABLE $1 \& 2$ here]}

Exploration of the differences and commonalities among the interventions reveals several trends. For example, all interventions that took place in Africa $(n=2)$ addressed only three behaviours and these behaviours did not include alcohol, stress, or sleep. Furthermore, none of the interventions in Africa use motivation as a mechanism. There was only one multiple health behaviour change intervention that took place in Central/South America $(n=1)$. This intervention was conducted in a clinical setting and was designed to address four behaviours simultaneously. On the other hand, Europe $(n=60)$ and North America $(n=49)$ had larger variations in the number and types of behaviours addressed by any given intervention. Europe and North America were the only continents in which sleep was also targeted within 
behavioural change interventions. North America was also the only region in which there were interventions that targeted all six behaviours simultaneously.

Overall, the majority of interventions employed at least 2 mechanisms. Specifically 31(22\%) interventions only used one mechanism, 66 (48\%) of interventions used two mechanisms, and 41 (30\%) targeted all three mechanisms. As shown in Table 1, 66 studies (48\%) were scored as 4 stars, 59 (43\%) were three stars, and $13(9 \%)$ were scored as two stars. Common reasons for why studies scored less than four stars included: lack of clarity around whether bias was sufficiently addressed, use of non-validated measures, insufficient description of randomization process (if applicable), high withdrawal/drop-out.

Demi-Regularity - Opportunity

For the purposes of this rapid realist review, "opportunity" was defined as "all the factors that lie outside the individual that make the behaviour possible or prompt it" [31]. When interventions focused on increasing the "opportunity" to access services and change the social environment, tobacco users who engaged in other unhealthy behaviours were more likely to achieve long term smoking cessation. In particular, interventions that: 1) provided access to healthy living "tools" (e.g. free medications such as nicotine replacement therapy, gym memberships, walking groups, free/accessible fruits and vegetables, etc.) and/or 2) encouraged social support (e.g. incorporating family members into care, interventions held social events).

Supporting evidence. There were 32 interventions $[40,56-86]$ that used opportunity as one of the mechanisms for behaviour change with the majority of these interventions $(59 \%)$ [40, 65-78, 81-84] reporting successful long term cessation. There were 12 interventions that aimed to increase access to resources as a part of the intervention $[60,62,65,66,69,70,76,77,81-84]$. Of these $10(83 \%)$ interventions reported successful long term smoking cessation $[65,66,69,70,76,77,81-84]$. The majority of interventions that made changes to the physical and/or social environment $(8 / 11 ; 73 \%)[40,65,66,68$, $73,81,82,84]$ or interventions that improved patient's social support system $(10 / 15 ; 67 \%)[65-68,71,72$, 74-76, 78] also reported successful long term cessation.

In various settings (e.g. clinical settings, community settings, workplace, etc.) and across several continents, programs that aimed to increase the opportunity to change behaviours were successful in achieving long term smoking abstinence among their participants (Table 3). These trends remain fairly consistent when examining all interventions; including those interventions that were rated from one to three stars in our quality assessment and reported statistical significance (see Additional File 3).

[INSTRUCTION TO JOURNAL: INSERT TABLE 3]

Demi-Regularity - Capability

For this review, capability was defined as the "individual's psychological and physical capacity to engage in healthy behaviours" [31]. The success of interventions that included capability as a mechanism appears to be dependent on various factors, including: the specific context in which these interventions 
were implemented, the populations that were targeted, and the types of behaviours targeted in the intervention. When examining specific techniques for increasing capability, including "capacity to plan", "enhancing knowledge" and "empowerment", the effectiveness of these techniques is dependent on the context in which it is implemented.

Supporting evidence. Of the 53 interventions in our sample that were based on this mechanism $[12,40$, 43, 56-105], only 23 (43\%) interventions resulted in long term smoking cessation [40, 65-78, 81-84, 102105]. Unlike the trends observed with opportunity, the majority of interventions that used capability as one of the mechanisms were not successful. These trends persisted when we looked at specific techniques for increasing capability. Only one [71] out of the four interventions $[64,71,89,90]$ that sought to change to one's beliefs about the intervention (a technique used to increase capability) reported successful long term smoking cessation.

However, there were certain contexts in which interventions based on this mechanism observed more success. Specifically, interventions that took place in Asia; four [67, 71, 84, 103, 104] out of eight interventions $[59,63,67,71,80,84,103,104]$ reported participants were more likely to quit smoking. Interventions that utilized capability in community based settings or in schools also had positive results with $71 \%(5 / 7)[40,70,77,81,104]$ and $80 \%(4 / 5)[40,73,82,84]$, respectively reporting long term smoking cessation.

There was only one observable trend among interventions that used capability to target primary prevention or secondary prevention. Interventions that targeted secondary prevention and aimed to empower participants did not appear to be effective. Only two $(40 \%)[67,71]$ out of the five interventions $[67,71,92,94,99]$ reported successful long term smoking cessation.

Conversely, there were certain contexts in which using capability as a mechanism appeared to negatively impact the success of the intervention. In Europe $(6 / 19 ; 32 \%)[40,70,74,78,83,102]$ and in Australasia $(2 / 5 ; 40 \%)[69,75]$, only a minority of the interventions using capability reported participants were more likely to quit smoking. Even when we examined specific techniques for increasing capability that were used in Europe, very few interventions reported successful long term smoking cessation. Similar trends were observed with interventions that took place in clinical settings; only $37 \%(10 / 27)[40,67,71,76,78$, $81,83,102-104]$ of the interventions reported participants were more likely to quit smoking.

The type and number of risk behaviours targeted by interventions that aimed to increase patient's capability were also examined (Table 4). Unlike what was observed for opportunity, using capability as a mechanism in an intervention only appeared to be successful for certain behaviours and when specific techniques for increasing capability were used. For example, among interventions that targeted stress, the majority of interventions $(6 / 10 ; 60 \%)[40,65,66,68,75,83]$ that used 'capacity to plan' demonstrated success in achieving long term smoking cessation. Furthermore, $60 \% ;(3 / 5)[65,71,75]$ of interventions that targeted alcohol and used 'empowerment' as a technique for increasing capability reported long term smoking cessation. However, only 33\% (1/3) of interventions [71] that targeted alcohol and used the technique of changing 'beliefs about the intervention' reported long term smoking cessation. 
[INSTRUCTION TO JOURNAL: INSERT TABLE 4]

Demi-regularity - Motivation

Motivation, defined as "all those brain processes that energize and direct behaviour, not just goals and conscious decision-making" [31], appears to be effective in certain contexts for improving smoking cessation outcomes.

Supporting evidence. Thirty seven interventions $[12,40,43,56,58,59,61,64-66,68,70,75-80,83,84,86$, $89,90,92,93,95-97,99-103,105-108]$ in our sample were based on a specific theory that increasing a patient's motivation would assist in quit smoking. Based on our criteria, there were very few techniques involving motivation that had any reportable trends. As a result, we have chosen to provide a descriptive overview of the trends for the overall motivation mechanism.

Interventions that included a component for increasing participant's motivation had mixed results, as $43 \%$ $(16 / 37)[40,65,66,68,70,75-78,83,84,102,103,105,107,108]$ of studies reported an association between increasing participant's motivation and long term smoking cessation. Similar to capability, implementing strategies that increased motivation within interventions appeared to be beneficial in certain contexts. For example, the majority of interventions that utilized motivation in community-based settings $(3 / 4 ; 75 \%)[40,70,77]$ and schools $(2 / 3 ; 67 \%)[40,84]$ reported that participants were more likely to quit smoking long term. In contrast, applying motivation as a mechanism was unsuccessful in clinical settings; eight $(36 \%)[40,76,78,83,102,103,107,108]$ out of the $22[12,40,43,58,64,76,78-80,83,86$, $89,92,93,95,99,100,102,103,106-108]$ interventions in these settings reported participants were more likely to quit smoking.

In terms of the number of behaviours that were targeted, interventions targeting three behaviours demonstrated limited success; only six $(32 \%)[77,78,84,102,103,107]$ of the $19[12,61,64,77-80,84,86$, $92,93,95,96,99,100,102,103,106,107]$ reported long term smoking cessation. The types of behaviours targeted by these interventions were also examined. The majority of interventions that focused on increasing patient's motivation and targeted stress $(8 / 12 ; 67 \%)[40,65,66,68,70,75,83,105]$ reported a greater likelihood of long term smoking cessation.

\section{Discussion}

Health behaviour change programs that address multiple behaviours have been the subject of much discussion because there are a multitude of ways in which these programs can be developed, including: the types and numbers of modifiable risk behaviours to target [109], the types of activities to use [31], and the types of professions to involve [110-112]. In the current literature, there is a clear gap in the understanding of why some interventions have worked and others have not [46]. The results of this rapid realist review are the first step in addressing this gap. Specifically, the goal of this paper was to review 
published interventions targeting multiple modifiable risk behaviours to uncover demi-regularities that contribute to the success of the program in helping people quit smoking. In other words, what contexts and mechanisms (i.e. structures, activities or processes within interventions that contribute to the outcomes of interest) lead to long-term smoking cessation.

The results of this rapid realist review emphasize the importance of incorporating mechanisms that modify external factors in multiple health behaviour interventions that attempt to achieve long term smoking cessation. Specifically, interventions that made resources (e.g. pharmacotherapy, exercise, healthy foods) more accessible, changed the physical environment (e.g. introduced smoke free polices), or increased one's social support network, were more likely to help individuals quit smoking. Evidence to support these findings was noticeable across different regions, settings, and behaviours. These findings challenge individualistic epidemiology that many health promotion interventions are based on, namely that health behaviours are a matter of individual choice [113]. While individuals do have 'free choice'; research shows that the environment can significantly influence the decisions they make [114-116].

The findings from this rapid realist review also show that the success of interventions targeting motivation and capability appears to be dependent on the context. For example, interventions in Asia that tried to increase capability were usually successful in helping people quit smoking, while European interventions were not. The literature shows that while smoking is no longer socially acceptable in North America and Europe $[117,118]$, for many countries in Asia (e.g. China) smoking continues to be an accepted social activity $[119,120]$. Thus it could be hypothesized that interventions that increase person's psychological capabilities (such as enhancing knowledge and skills) are more successful in contexts where the social climate was favourable to smoking. This finding is similar to previous research, which shows that the impact of knowledge on promoting successful behaviour change is dependent on the context in which it is provided $[121,122]$.

With regards to the trends we have observed with interventions that target motivation, the majority of these interventions did not appear to be successful in clinical settings but were successful in schools and community-based settings. A possible explanation for this is interventions delivered in non-clinic settings are reaching populations that are not motivated as they are not currently seeking out health care. Populations that are already in health care settings or seeking out health care are likely to be intrinsically motivated to make changes to their behaviours [24, 123-128]. Thus, it is likely only in settings where motivation is low that having programs focusing on increasing motivation made a difference.

Significant strides have been made in the field of tobacco control to reduce the smoking prevalence globally [129-131]. Tobacco control efforts have focused on changing the environment and the opportunities available to individuals (e.g. legislation introducing smoke-free places, warning-labels on tobacco products) [129-131], which is coincides with the demi-regularities we have found in our review. However, for many other modifiable risk factors including alcohol and physical activity, public health promotion has traditionally relied on education, information, and psychosocial interventions to persuade individuals to adopt healthy lifestyles $[132,133]$. Moreover, many widely used theories for behaviour 
change, including the Theory of Reasoned Action, Theory of Planned Behaviour, and the Trans-theoretical Model of Behaviour Change have focused primarily on the individual [134-136]. These theories do not account for the influence of environmental factors and thus may further contribute to the individualistic approach in addressing these risk factors. While some studies $(n=52(38 \%)$ in this review report using an established theory (e.g. Trans-theoretical Model of Behaviour Change), the majority did not report whether they used a theoretical framework $(n=86(62 \%)$. Thus we were unable to examine how the application of these theories within the interventions may have influenced the mechanisms that were targeted. In the current population of smokers, who engage in additional modifiable risk factors, this review shows that it is important for interventions to focus on changing an individual's opportunity to adopt additional healthy behaviours as well.

Using the COM-B model as our framework to categorize the mechanisms provided a systematic and standardized method to code the diverse interventions $[137,138]$. This method is aligned other reviews examining effective behaviour change interventions $[139,140]$. It also allowed us to use clearly-defined techniques that maps on to the COM-B model, and a behaviour change taxonomy; thereby ensuring transparency and enabling replication [31,32]. Focusing our analysis on mechanisms used in the COM-B model also allowed for documentation of internal and external drivers of behaviour change, something many other theories do not allow [134-136]. In addition, we were able to develop a high level of understanding of the general trends that influence whether a program that targets multiple health behaviors is effective to help people quit smoking. Therefore, using the COM-B model provided the first step in understanding the determinants of successful behaviour change. While the COM-B model has been criticized for ignoring contextual characteristics [141], this cannot be said for this rapid realist review as we also analyzed context as part of the C-M-O configuration. The COM-B model was used only to code the mechanisms and we subsequently examined the contexts which these mechanisms were operationalized.

However, there were some limitations to using the COM-B model as the framework for the mechanisms in the C-M-O configuration. As mentioned by other researcher [141], this model in its current form does not provide specific and tangible actions to incorporate into the design of an intervention. That being said the COM-B model can be mapped onto the Behaviour Change Wheel [31], which does provide specific recommendations for appropriate intervention functions that can be used to address each component of the COM-B. Thus findings from this study are not intended to be final; rather offer guidance on next steps in generating hypotheses for future intervention studies. The COM-B model provides directions on the mechanisms, and therefore, the areas of the Behaviour Change Wheel that should be explored further and in which contexts.

Also important to note is that Michie's group is currently developing and mapping Mechanisms of Action (MoA) to behaviour change techniques [142]. MoAs are defined as "the process through which behaviour change occurs" [142]. In the future, it might become useful to apply the findings of this review to the MoA. A recent publication by Carey and colleagues [143], which was published after we had started coding our work, has hypothesised some possible links between BCTs and MoA. The MoAs expressed in Carey's 
study are more granular than the ones we used in this study. However, since it is based on the Behaviour Change Technique Taxonomy we should be able to draw comparisons. For example, some the common MoAs identified by Carey et al include: knowledge, skills, behavioural regulations, attitudes towards the behaviour, beliefs about capability, and beliefs about consequences. These are all characteristics we identified and coded in each study and then grouped as "Capability" using the COM-B model's definition.

A major limitation of this review is that many of the articles reviewed did not describe the context or the behavioural change techniques used in detail. For example, we were unable to determine whether the setting in which an intervention took place already had other resources and supports that contributed to the success of the intervention (e.g. highly experienced staff). As a result, the contexts we were able to examine were broad, including: the continent in which the intervention took place and the type of setting (e.g. clinical, workplace). Given the wide variety in the types of populations that interventions targeted, we were not able to examine trends by target population.

Moreover, in some instances, the studies did not provide sufficient details on the types of activities undertaken as a part of the intervention. This under-reporting of active ingredients was recently discussed in a systematic review and meta-analysis of smoking cessation interventions [137, 138, 144]. Bruin et al. (2019) describe the challenge of reporting all the BCTs in a complex intervention as they can include 20 or more BCTs [144]. It has been shown that even a routine visit between patients and health care professionals can include 15 or more BCTs [145-147].

It is important to also acknowledge that there were several challenges associated with isolating the mechanisms within the interventions. Specifically, for studies with poor quality reporting in articles, study design, and/or implementation, it was often difficult to determine which mechanisms were targeted. To get around this challenge, we reviewed articles with four star quality ratings first to determine the demiregularities. However, these limitations also meant that, in some situations, we were unable to identify whether a specific mechanism was used. This may further contribute to under-reporting of the mechanisms targeted within the interventions.

Lastly, the majority of interventions in this review targeted at least two mechanisms simultaneously $(\mathrm{n}=$ $97,70 \%$ ). It is unclear the degree of overlap between mechanisms and how these mechanisms interact to produce the observed outcome in these interventions. As a result, there may have been additional mechanisms and techniques that were employed by these interventions that we were unable to capture in our analyses. Future areas of research should also include examining the order in which behaviours should be addressed, (simultaneously vs sequential), the combination of behaviours to target, and the combination of mechanisms to target.

\section{Conclusion}

Our study is the first to apply a realist review methodology to explore how, why and under what circumstances programs that target multiple risk behaviours are associated with long term smoking cessation. It offers an explanatory view of the existing and extensive body of literature on interventions 
targeting multiple health behaviours. The evidence we reviewed came from a variety of countries, continents, settings, and targeted different behaviours, and yet we were able to observe clear and consistent themes regarding the importance of increasing an individual's opportunity in multiple health behaviour change interventions. With regards to Picking Up the PACE, the results of this rapid realist review informed the development of courses for practitioners on how to support individuals who have multiple risk behaviours and are trying to quit smoking. Moving forward, programs and interventions that aim to address multiple modifiable risk factors as a part of a smoking cessation intervention should strongly consider incorporating components and activities intend to change factors that are external to the individual (i.e. social support, and access to treatment). The findings of the review highlight the value and importance of the COM-B model for effective behaviour change. We recommend that decisionmakers, policy makers and implementers who are aiming to design multiple health behaviour change interventions should consistently apply to the COM-B model, take context into consideration, and wherever feasible, include activities that improve an individual's opportunities to make successful behaviour change.

\section{Abbreviations}

C-M-O

Context, Mechanism, Outcome

COM-B

capability $(\mathrm{C})$, opportunity $(\mathrm{O})$, motivation $(\mathrm{M})$ - behaviour $(\mathrm{B})$

PACE

Promoting and Accelerating Change through Empowerment

\section{Declarations}

- Ethics approval and consent to participate: Not Applicable

- Consent for publication: Not Applicable

- Availability of data and material: The datasets used and/or analyzed during the current study are available from the corresponding author on reasonable request.

- Competing interests: The authors declare that they have no competing interest with respect to this rapid realist review; however some authors have general disclosures to report. Peter Selby reports receiving grants and/or salary from Centre for Addiction and Mental Health, Ontario Ministry of Health and Long-Term care, CIHR, Canadian Centre on Substance Use and Addiction, Public Health Agency of Canada, Medical Psychiatry Alliance, Canadian Cancer Society Research Institute, Cancer Care Ontario, and the Ontario Institute for Cancer Research. Peter Selby also reports receiving funding from the following commercial organizations Pfizer Inc./Pfizer Canada, Bhasin Consulting Fund, Shoppers Drug Mart and Patient-Centered Outcomes Research Institute; and has received consulting fees from Pfizer Inc./Pfizer Canada, Johnson \& Johnson Group of Companies, MedPlan Communications. Through an open tender process, Johnson \& Johnson, Novartis, and Pfizer Inc. are 
vendors of record for providing smoking cessation pharmacotherapy, free or discounted, for research studies in which Peter Selby is the principal investigator or co-investigator. Heather Manson reports employment with Public Health Ontario, and academic appointment as assistant professor at the University of Toronto and adjunct professor at the University of Waterloo. Wayne DeRuiter reports grant funding from Pfizer Inc. and Medical Psychiatry Alliance. Wayne DeRuiter also reports stock ownership in Abbott Laboratories.

- Funding: This project is supported by funds from the Public Health Agency of Canada (PS-PI) and the Medical Psychiatry Alliance (VT). The views do not reflect those of the funders.

- Authors' contributions: NM and PS conceptualized the study. NM led the design of the study. The search strategy was informed by all authors and developed and executed by TR. TC, ML, WD, OM, MW (acknowledgements), MR (acknowledgements), MP (acknowledgements), MA (acknowledgements), AL (acknowledgements) conducted the relevance confirmation TC, $\mathrm{CH}$ (acknowledgements), ML, NM, WD conducted the data extraction and quality assessment and TC, $\mathrm{ML}, \mathrm{NM}$ conducted the data analysis and significantly contributed to the manuscript preparation. All authors read and approved the final manuscript

- Acknowledgements: We would like to thank:

- Catherine Hierlihy who was instrumental in helping with data extraction and quality assessment.

- Mandavni Rathore, Melanie Wisener, Meera Pahwa, Magdalena Albrecht-Bisset, and Aidan Lehechka who helped with relevance confirmation.

- Peter Selby would like to acknowledge salary support for his clinician-scientist position from the Centre for Addiction and Mental Health and the Department of Family and Community Medicine at the University of Toronto.

- Heather Manson would like to acknowledge salary support from Public Health Ontario, a government agency.

\section{References}

1. Organization WH. WHO Report on the Global Tobacco Epidemic, 2019. Geneva: 2019.

2. Services USDoHaH. The Health Consequences of Smoking-50 Years of Progress: A Report of the Surgeon General. Atlanta: 2014.

3. Xu X, Bishop EE, Kennedy SM, Simpson SA, Pechacek TF. Annual healthcare spending attributable to cigarette smoking: an update. American journal of preventive medicine. 2015;48(3):326-33.

4. Drobescu A, Bhandari A, Sutherland G, Dinh T. The Cost of Tobacco Use in Canada, 2012. Ottawa: 2017.

5. Baker CL, Flores NM, Zou KH, Bruno M, Harrison VJ. Benefits of quitting smoking on work productivity and activity impairment in the United States, the European Union and China. 
International journal of clinical practice. 2017;71(1):e12900.

6. Prevention CfDCa. Smoking is down, but almost 38 million American adults still smoke: Centers for Disease Control and Prevention; 2018 [cited 2019 January 13]. Available from: https://www.cdc.gov/media/releases/2018/p0118-smoking-rates-declining.html.

7. Canada S. Health Fact Sheets: Smoking, 2018: Government of Canada; 2019 [cited 2019 January 13]. Available from: https://www150.statcan.gc.ca/n1/en/pub/82-625-x/2019001/article/00006eng.pdf?st=gp6vgv1s.

8. Creamer MR, Wang TW, Babb S, Cullen KA, Day H, Willis G, et al. Tobacco product use and cessation indicators among adults-United States, 2018. Morbidity and Mortality Weekly Report. 2019;68(45):1013.

9. Meader N, King K, Moe-Byrne T, Wright K, Graham H, Petticrew M, et al. A systematic review on the clustering and co-occurrence of multiple risk behaviours. BMC Public Health. 2016;16(1):657.

10. Emmons KM, Marcus BH, Linnan L, Rossi JS, Abrams DB. Mechanisms in multiple risk factor interventions: smoking, physical activity, and dietary fat intake among manufacturing workers. Preventive Medicine: An International Journal Devoted to Practice and Theory. 1994.

11. Chiolero A, Wietlisbach V, Ruffieux C, Paccaud F, Cornuz J. Clustering of risk behaviors with cigarette consumption: a population-based survey. Prev Med. 2006;42(5):348-53.

12. Baker AL, Richmond R, Kay-Lambkin FJ, Filia SL, Castle D, Williams JM, et al. Randomized controlled trial of a healthy lifestyle intervention among smokers with psychotic disorders. Nicotine \& tobacco research : official journal of the Society for Research on Nicotine and Tobacco. 2015;17(8):946-54.

13. Ussher MH, Taylor A, Faulkner G. Exercise interventions for smoking cessation. Cochrane Database of Syst Rev. 2012(1).

14. Azagba S, Sharaf MF. The effect of job stress on smoking and alcohol consumption. Health economics review. 2011;1(1):15.

15. Romberger DJ, Grant K. Alcohol consumption and smoking status: the role of smoking cessation. Biomedicine \& pharmacotherapy. 2004;58(2):77-83.

16. Butterfield RM, Park ER, Puleo E, Mertens A, Gritz ER, Li FP, et al. Multiple risk behaviors among smokers in the childhood cancer survivors study cohort. Psycho-Oncology: Journal of the Psychological, Social and Behavioral Dimensions of Cancer. 2004;13(9):619-29.

17. Sherwood NE, Hennrikus DJ, Jeffery RW, Lando HA, Murray DM. Smokers with multiple behavioral risk factors: how are they different? Preventive medicine. 2000;31(4):299-307.

18. Hughes JR, Keely J, Naud S. Shape of the relapse curve and long-term abstinence among untreated smokers. Addiction. 2004;99(1):29-38.

19. Ebrahim S, Beswick A, Burke M, Smith GD. Multiple risk factor interventions for primary prevention of coronary heart disease. The Cochrane database of systematic reviews. 2006(4):CD001561.

20. Excellence NIfC, Britain G. Brief interventions and referral for smoking cessation in primary care and other settings: NICE; 2006. 
21. West R, McNeill A, Raw M. Smoking cessation guidelines for health professionals: an update. Thorax. 2000;55(12):987-99.

22. McRobbie H, Bullen C, Glover M, Whittaker R, Wallace-Bell M, Fraser T. New Zealand smoking cessation guidelines. The New Zealand Medical Journal (Online). 2008;121(1276).

23. Fiore MC, Bailey WC, Cohen SJ, Dorfman SF, Goldstein MG, Gritz ER, et al. Treating tobacco use and dependence: clinical practice guideline. Rockville, MD: US Department of Health and Human Services, Public Health Service; 2000.

24. Ebrahim S, Taylor F, Ward K, Beswick A, Burke M, Davey Smith G. Multiple risk factor interventions for primary prevention of coronary heart disease. Cochrane Database Syst Rev. 2011;1(1):CD001561.

25. Uthman OA, Hartley L, Rees K, Taylor F, Ebrahim S, Clarke A. Multiple risk factor interventions for primary prevention of cardiovascular disease in low-and middle-income countries. Cochrane Database Syst Rev. 2015;8:CD011163.

26. Ussher MH, Taylor AH, Faulkner GE. Exercise interventions for smoking cessation. The Cochrane database of systematic reviews. 2014(8).

27. Prochaska JJ, Delucchi K, Hall SM. A meta-analysis of smoking cessation interventions with individuals in substance abuse treatment or recovery. Journal of consulting and clinical psychology. 2004;72(6):1144.

28. Meader N, King K, Wright K, Graham HM, Petticrew M, Power C, et al. Multiple risk behavior interventions: meta-analyses of RCTs. Am J Prev Med. 2017;53(1):e19-e30.

29. Pawson R, Greenhalgh T, Harvey G, Walshe K. Realist synthesis: an introduction. Manchester: ESRC Research Methods Programme, University of Manchester. 2004.

30. Pawson R, Greenhalgh T, Harvey G, Walshe K. Realist review-a new method of systematic review designed for complex policy interventions. Journal of health services research \& policy. 2005;10(1_suppl):21-34.

31. Michie S, Van Stralen MM, West R. The behaviour change wheel: a new method for characterising and designing behaviour change interventions. Implementation science. 2011;6(1):42.

32. Abraham C, Michie S. A taxonomy of behavior change techniques used in interventions. Health psychology. 2008;27(3):379.

33. Pawson R. Evidence-based policy: The promise ofrealist synthesis'. Evaluation. 2002;8(3):340-58.

34. Pawson R. Evidence-based policy: a realist perspective: sage; 2006.

35. Saul JE, Willis CD, Bitz J, Best A. A time-responsive tool for informing policy making: rapid realist review. Implementation Science. 2013;8(1):103.

36. Saul JE, Willis CD, Bitz J, Best A. A time-responsive tool for informing policy making: the rise of Rapid Realist Review.

37. Minian N, DeRuiter W, Lingam M, Corrin T, Dragonetti R, Manson H, et al. The effects of interventions targeting multiple health behaviors on smoking cessation outcomes: a rapid realist review protocol. Systematic reviews. 2018;7(1):38. 
38. Wong G, Greenhalgh T, Westhorp G, Buckingham J, Pawson R. RAMESES publication standards: realist syntheses. BMC medicine. 2013;11(1):21.

39. Group MRFITR. Mortality rates after 10.5 years for participants in the Multiple Risk Factor Intervention Trial. Findings related to a priori hypotheses of the trial. JAMA. 1990;263(13):1795-801.

40. Puska P, Nissinen A, Tuomilehto J, Salonen JT, Koskela K, McAlister A, et al. The community-based strategy to prevent coronary heart disease: conclusions from the ten years of the North Karelia project. Annu Rev Public Health. 1985;6(1):147-93.

41. Farquhar JW, Fortmann SP, Flora JA, Taylor CB, Haskell WL, Williams PT, et al. Effects of communitywide education on cardiovascular disease risk factors: the Stanford Five-City Project. Jama. 1990;264(3):359-65.

42. Grunfeld E, Manca D, Moineddin R, Thorpe KE, Hoch JS, Campbell-Scherer D, et al. Improving chronic disease prevention and screening in primary care: results of the BETTER pragmatic cluster randomized controlled trial. BMC family practice. 2013;14(1):175.

43. Emmons KM, McBride CM, Puleo E, Pollak KI, Clipp E, Kuntz K, et al. Project PREVENT: a randomized trial to reduce multiple behavioral risk factors for colon cancer. Cancer Epidemiology and Prevention Biomarkers. 2005;14(6):1453-9.

44. Toobert DJ, Strycker LA, Glasgow RE, Barrera M, Bagdade JD. Enhancing support for health behavior change among women at risk for heart disease: the Mediterranean Lifestyle Trial. Health Education Research. 2002;17(5):574-85.

45. Luepker RV, Murray DM, Jacobs Jr DR, Mittelmark MB, Bracht N, Carlaw R, et al. Community education for cardiovascular disease prevention: risk factor changes in the Minnesota Heart Health Program. American journal of public health. 1994;84(9):1383-93.

46. Prochaska JJ, Prochaska JO. A review of multiple health behavior change interventions for primary prevention. American journal of lifestyle medicine. 2011;5(3):208-21.

47. King K, Meader N, Wright K, Graham H, Power C, Petticrew M, et al. Characteristics of interventions targeting multiple lifestyle risk behaviours in adult populations: a systematic scoping review. PloS one. 2015;10(1):e0117015.

48. Ebrahim S, Davey GS. Multiple risk factor interventions for primary prevention of coronary heart disease. The cochrane database of systematic reviews. 2000(2):CD001561-CD.

49. Partners E. DistillerSR (Version 2) 2017. Available from: https://www.evidencepartners.com/products/distillersr-systematic-review-software/.

50. Pace R, Pluye P, Bartlett G, Macaulay AC, Salsberg J, J J, et al. Testing the reliability and efficiency of the pilot Mixed Methods Appraisal Tool (MMAT) for systematic mixed studies review. International Journal of Nursing Studies. 2012;49(1):47-53.

51. CASP. Critical Appraisal Skills Programme - CASP Appraisal Checklists: CASP UK; 2018 [cited 2018]. Available from: https://casp-uk.net/casp-tools-checklists/.

52. NVivo Qualitative Data Analysis Software [Internet]. 2015. 
53. Vartiainen E, Seppälä T, Lillsunde P, Puska P. Validation of self reported smoking by serum cotinine measurement in a community-based study. Journal of Epidemiology \& Community Health. 2002;56(3):167-70.

54. Studts JL, Ghate SR, Gill JL, Studts CR, Barnes CN, LaJoie AS, et al. Validity of self-reported smoking status among participants in a lung cancer screening trial. Cancer Epidemiology and Prevention Biomarkers. 2006;15(10):1825-8.

55. Patrick DL, Cheadle A, Thompson DC, Diehr P, Koepsell T, Kinne S. The validity of self-reported smoking: a review and meta-analysis. American journal of public health. 1994;84(7):1086-93.

56. Salisbury C, O'Cathain A, Thomas C, Edwards L, Gaunt D, Dixon P, et al. Telehealth for patients at high risk of cardiovascular disease: pragmatic randomised controlled trial. BMJ. 2016;353:i2647.

57. Griffin SJ, Simmons RK, Prevost AT, Williams KM, Hardeman W, Sutton S, et al. Multiple behaviour change intervention and outcomes in recently diagnosed type 2 diabetes: the ADDITION-Plus randomised controlled trial. Diabetologia. 2014;57(7):1308-19.

58. Vrdoljak D, Markovic BB, Puljak L, Lalic DI, Kranjcevic K, Vucak J. Lifestyle intervention in general practice for physical activity, smoking, alcohol consumption and diet in elderly: a randomized controlled trial. Arch Gerontol Geriatr. 2014;58(1):160-9.

59. Huang JJ, Lin HS, Yen M, Kan WM, Lee BO, Chen CH. Effects of a workplace multiple cardiovascular disease risks reduction program. Asian Nurs Res (Korean Soc Nurs Sci). 2013;7(2):74-82.

60. Han HR, Kim J, Kim KB, Jeong S, Levine D, Li C, et al. Implementation and success of nurse telephone counseling in linguistically isolated Korean American patients with high blood pressure. Patient Educ Couns. 2010;80(1):130-4.

61. Milani RV, Lavie CJ. Impact of worksite wellness intervention on cardiac risk factors and one-year health care costs. Am J Cardiol. 2009;104(10):1389-92.

62. Bhiri S, Maatoug J, Zammit N, Msakni Z, Harrabi I, Amimi S, et al. A 3-Year Workplace-Based Intervention Program to Control Noncommunicable Disease Risk Factors in Sousse, Tunisia. J Occup Environ Med. 2015;57(7):e72-7.

63. Wan LH, Zhang XP, Mo MM, Xiong XN, Ou CL, You LM, et al. Effectiveness of Goal-Setting Telephone Follow-Up on Health Behaviors of Patients with Ischemic Stroke: A Randomized Controlled Trial. J Stroke Cerebrovasc Dis. 2016;25(9):2259-70.

64. Kanera IM, Bolman CA, Willems RA, Mesters I, Lechner L. Lifestyle-related effects of the web-based Kanker Nazorg Wijzer (Cancer Aftercare Guide) intervention for cancer survivors: a randomized controlled trial. J Cancer Surviv. 2016;10(5):883-97.

65. Henke RM, Goetzel RZ, McHugh J, Isaac F. Recent experience in health promotion at Johnson \& Johnson: lower health spending, strong return on investment. Health Aff (Millwood). 2011;30(3):4909.

66. Long DA, Sheehan P. A case study of population health improvement at a Midwest regional hospital employer. Popul Health Manag. 2010;13(3):163-73. 
67. Shalaeva EV, Saner H, Janabaev BB, Shalaeva AV. Tenfold risk increase of major cardiovascular events after high limb amputation with non-compliance for secondary prevention measures. Eur $\mathrm{J}$ Prev Cardiol. 2017;24(7):708-16.

68. Kuehl KS, Elliot DL, MacKinnon DP, O'Rourke HP, DeFrancesco C, Miocevic M, et al. The SHIELD (Safety \& Health Improvement: Enhancing Law Enforcement Departments) Study: Mixed Methods Longitudinal Findings. J Occup Environ Med. 2016;58(5):492-8.

69. Jelinek MV, Santamaria JD, Best JD, Thompson DR, Tonkin AM, Vale MJ. Reversing social disadvantage in secondary prevention of coronary heart disease. Int J Cardiol. 2014;171(3):346-50.

70. Gibson I, Flaherty G, Cormican S, Jones J, Kerins C, Walsh AM, et al. Translating guidelines to practice: findings from a multidisciplinary preventive cardiology programme in the west of Ireland. Eur J Prev Cardiol. 2014;21(3):366-76.

71. Xavier D, Gupta R, Kamath D, Sigamani A, Devereaux PJ, George N, et al. Community health workerbased intervention for adherence to drugs and lifestyle change after acute coronary syndrome: a multicentre, open, randomised controlled trial. The Lancet Diabetes \& Endocrinology. 2016;4(3):24453.

72. Kim JY, Wineinger NE, Steinhubl SR. The Influence of Wireless Self-Monitoring Program on the Relationship Between Patient Activation and Health Behaviors, Medication Adherence, and Blood Pressure Levels in Hypertensive Patients: A Substudy of a Randomized Controlled Trial. J Med Internet Res. 2016;18(6):e116.

73. Dendana E, Ghammem R, Sahli J, Maatoug J, Fredj SB, Harrabi I, et al. Clustering of chronic diseases risk factors among adolescents: a quasi-experimental study in Sousse, Tunisia. Int J Adolesc Med Health. 2017.

74. Gomez-Pardo E, Fernandez-Alvira JM, Vilanova M, Haro D, Martinez R, Carvajal I, et al. A Comprehensive Lifestyle Peer Group-Based Intervention on Cardiovascular Risk Factors: The Randomized Controlled Fifty-Fifty Program. J Am Coll Cardiol. 2016;67(5):476-85.

75. Baker A, Richmond R, Castle D, Kulkarni J, Kay-Lambkin F, Sakrouge R, et al. Coronary heart disease risk reduction intervention among overweight smokers with a psychotic disorder: pilot trial. Aust N Z J Psychiatry. 2009;43(2):129-35.

76. Holtrop JS, Dosh SA, Torres T, Thum YM. The community health educator referral liaison (CHERL): a primary care practice role for promoting healthy behaviors. Am J Prev Med. 2008;35(5 Suppl):S36572.

77. Becker DM, Yanek LR, Johnson WR, Jr., Garrett D, Moy TF, Reynolds SS, et al. Impact of a communitybased multiple risk factor intervention on cardiovascular risk in black families with a history of premature coronary disease. Circulation. 2005;111(10):1298-304.

78. Ofori SN, Kotseva K. Comparison of treatment outcomes in patients with and without diabetes mellitus attending a multidisciplinary cardiovascular prevention programme (a retrospective analysis of the EUROACTION trial). BMC Cardiovasc Disord. 2015;15:11. 
79. Speyer H, Nørgaard HCB, Birk M, Karlsen M, Jakobsen AS, Pedersen K, et al. The CHANGE trial: no superiority of lifestyle coaching plus care coordination plus treatment as usual compared to treatment as usual alone in reducing risk of cardiovascular disease in adults with schizophrenia spectrum disorders and abdominal obesity. World Psychiatry. 2016;15(2):155.

80. Jiang X, Sit JW, Wong TK. A nurse-led cardiac rehabilitation programme improves health behaviours and cardiac physiological risk parameters: evidence from Chengdu, China. Journal of clinical nursing. 2007;16(10):1886-97.

81. Plescia M, Herrick H, Chavis L. Improving health behaviors in an African American community: the Charlotte Racial and Ethnic Approaches to Community Health project. American Journal of Public Health. 2008;98(9):1678-84.

82. Frank E, Elon L, Hertzberg V. A quantitative assessment of a 4-year intervention that improved patient counseling through improving medical student health. Medscape General Medicine. 2007;9(2):58.

83. Jolly K, Taylor R, Lip G, Greenfield S, Raftery J, Mant J, et al. The Birmingham Rehabilitation Uptake Maximisation Study (BRUM). Home-based compared with hospital-based cardiac rehabilitation in a multi-ethnic population: cost-effectiveness and patient adherence. Health Technology Assessment (Winchester, England). 2007;11(35):1-118.

84. Saraf DS, Gupta SK, Pandav CS, Nongkinrih B, Kapoor SK, Pradhan SK, et al. Effectiveness of a school based intervention for prevention of non-communicable diseases in middle school children of rural North India: a randomized controlled trial. Indian J Pediatr. 2015;82(4):354-62.

85. Kronish IM, Rieckmann N, Burg MM, Edmondson D, Schwartz JE, Davidson KW. The effect of enhanced depression care on adherence to risk-reducing behaviors after acute coronary syndromes: findings from the COPES trial. Am Heart J. 2012;164(4):524-9.

86. van Lieshout J, Huntink E, Koetsenruijter J, Wensing M. Tailored implementation of cardiovascular risk management in general practice: a cluster randomized trial. Implementation Science. 2015;11(1):115.

87. Almeida OP, Marsh K, Murray K, Hickey M, Sim M, Ford A, et al. Reducing depression during the menopausal transition with health coaching: Results from the healthy menopausal transition randomised controlled trial. Maturitas. 2016;92:41-8.

88. Broekhuizen K, van Poppel MN, Koppes LL, Kindt I, Brug J, van Mechelen W. Can multiple lifestyle behaviours be improved in people with familial hypercholesterolemia? Results of a parallel randomised controlled trial. PLoS One. 2012;7(12):e50032.

89. Butler CC, Simpson SA, Hood K, Cohen D, Pickles T, Spanou C, et al. Training practitioners to deliver opportunistic multiple behaviour change counselling in primary care: a cluster randomised trial. Bmj. 2013;346:f1191.

90. Cameron D, Epton T, Norman P, Sheeran P, Harris PR, Webb TL, et al. A theory-based online health behaviour intervention for new university students (U@Uni:LifeGuide): results from a repeat randomized controlled trial. Trials. 2015;16:555. 
91. Echouffo-Tcheugui JB, Simmons RK, Prevost AT, Williams KM, Kinmonth AL, Wareham NJ, et al. Long-term effect of population screening for diabetes on cardiovascular morbidity, self-rated health, and health behavior. Ann Fam Med. 2015;13(2):149-57.

92. Hjorth P, Medici CR, Juel A, Madsen NJ, Vandborg K, Munk-Jorgensen P. Improving quality of life and physical health in patients with schizophrenia: A 30-month program carried out in a real-life setting. Int J Soc Psychiatry. 2017;63(4):287-96.

93. Hyman DJ, Pavlik VN, Taylor WC, Goodrick GK, Moye L. Simultaneous vs sequential counseling for multiple behavior change. Archives of Internal Medicine. 2007;167(11):1152-8.

94. Ibfelt E, Rottmann N, Kjaer T, Hoybye MT, Ross L, Frederiksen K, et al. No change in health behavior, $\mathrm{BMI}$ or self-rated health after a psychosocial cancer rehabilitation: Results of a randomized trial. Acta Oncol. 2011;50(2):289-98.

95. Lakerveld J, Bot SD, Chinapaw MJ, van Tulder MW, Kostense PJ, Dekker JM, et al. Motivational interviewing and problem solving treatment to reduce type 2 diabetes and cardiovascular disease risk in real life: a randomized controlled trial. International Journal of Behavioral Nutrition and Physical Activity. 2013;10(1):47.

96. McClure JB, Catz SL, Ludman EJ, Richards J, Riggs K, Grothaus L. Feasibility and acceptability of a multiple risk factor intervention: The Step Up randomized pilot trial. BMC public health. 2011;11(1):167.

97. Merrill RM, Anderson A, Thygerson SM. Effectiveness of a worksite wellness program on health behaviors and personal health. J Occup Environ Med. 2011;53(9):1008-12.

98. Parekh S, King D, Boyle FM, Vandelanotte C. Randomized controlled trial of a computer-tailored multiple health behaviour intervention in general practice: 12-month follow-up results. International Journal of Behavioral Nutrition and Physical Activity. 2014;11(1):41.

99. Rosenberg D, Lin E, Peterson D, Ludman E, Von Korff M, Katon W. Integrated medical care management and behavioral risk factor reduction for multicondition patients: behavioral outcomes of the TEAMcare trial. Gen Hosp Psychiatry. 2014;36(2):129-34.

100. Shlay JC, Barber B, Mickiewicz T, Maravi M, Drisko J, Estacio R, et al. Peer Reviewed: Reducing Cardiovascular Disease Risk Using Patient Navigators, Denver, Colorado, 2007-2009. Preventing chronic disease. 2011;8(6).

101. Wister A, Loewen N, Kennedy-Symonds H, McGowan B, McCoy B, Singer J. One-year follow-up of a therapeutic lifestyle intervention targeting cardiovascular disease risk. CMAJ. 2007;177(8):859-65.

102. López ML, Iglesias JM, del Valle MO, Comas Á, Fernández JM, De Vries H, et al. Impact of a primary care intervention on smoking, drinking, diet, weight, sun exposure, and work risk in families with cancer experience. Cancer Causes \& Control. 2007;18(5):525-35.

103. Naser A, Shahamfar J, Kumar GV, Daga M, Hadi HS, Saeed D. Cardiac risk factor changes through an intensive multifactorial life style modification program in CHD patients: results from a two year follow up. J Biol Sci. 2008;8(2):248-57. 
104. Tobari H, Arimoto T, Shimojo N, Yuhara K, Noda H, Yamagishi K, et al. Physician-pharmacist cooperation program for blood pressure control in patients with hypertension: a randomizedcontrolled trial. Am J Hypertens. 2010;23(10):1144-52.

105. White JC, Hartley S, Ozminkowski RJ. Association Between Corporate Wellness Program Participation and Changes in Health Risks. J Occup Environ Med. 2015;57(10):1119-26.

106. Knekt $P$, Laaksonen MA, Raitasalo R, Haaramo $P$, Lindfors $O$. Changes in lifestyle for psychiatric patients three years after the start of short- and long-term psychodynamic psychotherapy and solution-focused therapy. Eur Psychiatry. 2010;25(1):1-7.

107. Ruffin MTt, Nease DE, Jr., Sen A, Pace WD, Wang C, Acheson LS, et al. Effect of preventive messages tailored to family history on health behaviors: the Family Healthware Impact Trial. Ann Fam Med. 2011;9(1):3-11.

108. van den Wijngaart LS, Sieben A, van der Vlugt M, de Leeuw FE, Bredie SJ. A nurse-led multidisciplinary intervention to improve cardiovascular disease profile of patients. West $\mathrm{J}$ Nurs Res. 2015;37(6):705-23.

109. Wilson K, Senay I, Durantini M, Sánchez F, Hennessy M, Spring B, et al. When it comes to lifestyle recommendations, more is sometimes less: A meta-analysis of theoretical assumptions underlying the effectiveness of interventions promoting multiple behavior domain change. Psychological bulletin. 2015;141(2):474.

110. Ockene JK, Adams A, Hurley TG, Wheeler EV, Hebert JR. Brief physician-and nurse practitionerdelivered counseling for high-risk drinkers: does it work? Archives of internal medicine. 1999;159(18):2198-205.

111. Kaner E, Heather N, Brodie J, Lock CA, McAvoy BR. Patient and practitioner characteristics predict brief alcohol intervention in primary care. Br J Gen Pract. 2001;51(471):822-7.

112. Landsperger JS, Semler MW, Wang L, Byrne DW, Wheeler AP. Outcomes of nurse practitionerdelivered critical care: a prospective cohort study. Chest. 2016;149(5):1146-54.

113. Stulberg B. The Key to Changing Individual Health Behaviors: Change the Environments That Give Rise to Them. Harvard Public Health Review. 2014;2.

114. Read D, Van Leeuwen B. Predicting hunger: The effects of appetite and delay on choice. Organizational behavior and human decision processes. 1998;76(2):189-205.

115. Van Ittersum K, Wansink B. Plate size and color suggestibility: the Delboeuf Illusion's bias on serving and eating behavior. Journal of Consumer Research. 2011;39(2):215-28.

116. Johnson EJ, Goldstein D. Do defaults save lives? Science. 2003:1338-40.

117. Cummings KM, Proctor RN. The changing public image of smoking in the United States: 1964-2014. Cancer Epidemiology and Prevention Biomarkers. 2014;23(1):32-6.

118. Organization WH. European Tobacco Use Trends Report 2019. Denmark: 2019.

119. Ma GX, Shive SE, Ma XS, Toubbeh JI, Tan Y, Lan YJ, et al. Social influences on cigarette smoking among mainland Chinese and Chinese Americans: a comparative study. American journal of health 
studies. 2013;28(1):12.

120. Yang G, Wang Y, Wu Y, Yang J, Wan X. The road to effective tobacco control in China. The Lancet. 2015;385(9972):1019-28.

121. Cane J, O'Connor D, Michie S. Validation of the theoretical domains framework for use in behaviour change and implementation research. Implementation science. 2012;7(1):37.

122. Taylor N, Lawton R, Conner M. Development and initial validation of the determinants of physical activity questionnaire. International Journal of Behavioral Nutrition and Physical Activity. 2013;10(1):74.

123. Ammerman AS, Lindquist $\mathrm{CH}$, Lohr KN, Hersey J. The efficacy of behavioral interventions to modify dietary fat and fruit and vegetable intake: a review of the evidence. Preventive medicine. 2002;35(1):25-41.

124. Hardcastle SJ, Taylor AH, Bailey MP, Harley RA, Hagger MS. Effectiveness of a motivational interviewing intervention on weight loss, physical activity and cardiovascular disease risk factors: a randomised controlled trial with a 12-month post-intervention follow-up. International journal of behavioral nutrition and physical activity. 2013;10(1):40.

125. Ketola E, Sipilä R, Mäkelä M. Effectiveness of individual lifestyle interventions in reducing cardiovascular disease and risk factors. Annals of medicine. 2000;32(4):239-51.

126. Norris SL, Engelgau MM, Narayan KV. Effectiveness of self-management training in type 2 diabetes: a systematic review of randomized controlled trials. Diabetes care. 2001;24(3):561-87.

127. Norris SL, Nichols PJ, Caspersen CJ, Glasgow RE, Engelgau MM, Jack Jr L, et al. Increasing diabetes self-management education in community settings: a systematic review. American journal of preventive medicine. 2002;22(4):39-66.

128. Murchie P, Campbell NC, Ritchie LD, Simpson JA, Thain J. Secondary prevention clinics for coronary heart disease: four year follow up of a randomised controlled trial in primary care. Bmj. 2003;326(7380):84.

129. Frazer K, Callinan JE, McHugh J, van Baarsel S, Clarke A, Doherty K, et al. Legislative smoking bans for reducing harms from secondhand smoke exposure, smoking prevalence and tobacco consumption. Cochrane Database of Systematic Reviews. 2016(2).

130. Bala MM, Strzeszynski L, Topor-Madry R. Mass media interventions for smoking cessation in adults. Cochrane Database of Systematic Reviews. 2017(11).

131. McNeill A, Gravely S, Hitchman SC, Bauld L, Hammond D, Hartmann-Boyce J. Tobacco packaging design for reducing tobacco use. Cochrane Database of Systematic Reviews. 2017(4).

132. Samdal GB, Eide GE, Barth T, Williams G, Meland E. Effective behaviour change techniques for physical activity and healthy eating in overweight and obese adults; systematic review and metaregression analyses. International Journal of Behavioral Nutrition and Physical Activity. 2017;14(1):42.

133. Michie S, Whittington C, Hamoudi Z, Zarnani F, Tober G, West R. Identification of behaviour change techniques to reduce excessive alcohol consumption. Addiction. 2012;107(8):1431-40. 
134. Ajzen I. The theory of planned behavior. Organizational behavior and human decision processes. 1991;50(2):179-211.

135. Sheppard BH, Hartwick J, Warshaw PR. The theory of reasoned action: A meta-analysis of past research with recommendations for modifications and future research. Journal of consumer research. 1988;15(3):325-43.

136. Prochaska JO, Velicer WF. The transtheoretical model of health behavior change. American journal of health promotion. 1997;12(1):38-48.

137. Glidewell L, Willis TA, Petty D, Lawton R, McEachan RR, Ingleson E, et al. To what extent can behaviour change techniques be identified within an adaptable implementation package for primary care? A prospective directed content analysis. Implementation Science. 2018;13(1):32.

138. Bartlett YK, Sheeran P, Hawley MS. Effective behaviour change techniques in smoking cessation interventions for people with chronic obstructive pulmonary disease: A meta-analysis. British Journal of Health Psychology. 2014;19(1):181-203.

139. Michie S, Abraham C, Whittington C, McAteer J, Gupta S. Effective techniques in healthy eating and physical activity interventions: a meta-regression. Health Psychology. 2009;28(6):690.

140. Dombrowski SU, Sniehotta FF, Avenell A, Johnston M, MacLennan G, Araújo-Soares V. Identifying active ingredients in complex behavioural interventions for obese adults with obesity-related comorbidities or additional risk factors for co-morbidities: a systematic review. Health Psychology Review. 2012;6(1):7-32.

141. Peters G-JY, De Bruin M, Crutzen R. Everything should be as simple as possible, but no simpler: towards a protocol for accumulating evidence regarding the active content of health behaviour change interventions. Health Psychology Review. 2015;9(1):1-14.

142. Connell LE, Carey RN, de Bruin M, Rothman AJ, Johnston M, Kelly MP, et al. Links between behavior change techniques and mechanisms of action: an expert consensus study. Annals of Behavioral Medicine. 2018.

143. Carey RN, Connell LE, Johnston M, Rothman AJ, de Bruin M, Kelly MP, et al. Behavior change techniques and their mechanisms of action: a synthesis of links described in published intervention literature. Annals of Behavioral Medicine. 2019;53(8):693-707.

144. de Bruin M, Black N, Javornik N, Viechtbauer W, Eisma M, Hartman-Boyce J, et al. Underreporting of the active content of behavioural interventions: A systematic review and meta-analysis of randomized trials of smoking cessation interventions. Health Psychology Review. 2019(justaccepted):1-33.

145. de Bruin M, Dima AL, Texier N, van Ganse E. Explaining the amount and consistency of medical care and self-management support in asthma: a survey of primary care providers in France and the United Kingdom. The Journal of Allergy and Clinical Immunology: In Practice. 2018;6(6):1916-25. e7.

146. Oberjé EJ, Dima AL, Pijnappel FJ, Prins JM, de Bruin M. Assessing treatment-as-usual provided to control groups in adherence trials: exploring the use of an open-ended questionnaire for identifying behaviour change techniques. Psychology \& health. 2015;30(8):897-910. 
147. Lorencatto F, West R, Stavri Z, Michie S. How well is intervention content described in published reports of smoking cessation interventions? Nicotine \& Tobacco Research. 2013;15(7):1273-82.

148. Wang Y, Xie B, Tao Y, Ma Y, Zhang K. Impact of Community-Based Integrated Traditional Chinese and Western Medicine Metabolic Syndrome Intervention Technology in Rural Residents in Southern Jiangsu, China. Med Sci Monit. 2015;21:2163-9.

149. Mastrangelo G, Marangi G, Bontadi D, Fadda E, Cegolon L, Bortolotto M, et al. A worksite intervention to reduce the cardiovascular risk: proposal of a study design easy to integrate within Italian organization of occupational health surveillance. BMC Public Health. 2015;15:12.

150. Saltychev M, Laimi K, El-Metwally A, Oksanen T, Pentti J, Virtanen M, et al. Effectiveness of multidisciplinary early rehabilitation in reducing behaviour-related risk factors. $\mathrm{J}$ Rehabil Med. 2012;44(4):370-7.

151. Laaksonen E, Vuoristo-Myllys S, Koski-Jannes A, Alho H. Combining medical treatment and CBT in treating alcohol-dependent patients: effects on life quality and general well-being. Alcohol Alcohol. 2013;48(6):687-93.

152. Eckman MH, Wise R, Leonard AC, Dixon E, Burrows C, Khan F, et al. Impact of health literacy on outcomes and effectiveness of an educational intervention in patients with chronic diseases. Patient Educ Couns. 2012;87(2):143-51.

153. O'brien LM, Polacsek M, MacDonald PB, Ellis J, Berry S, Martin M. Impact of a school health coordinator intervention on health-related school policies and student behavior. Journal of School Health. 2010;80(4):176-85.

154. Wendel-Vos GC, Dutman AE, Verschuren WM, Ronckers ET, Ament A, van Assema P, et al. Lifestyle factors of a five-year community-intervention program: the Hartslag Limburg intervention. Am J Prev Med. 2009;37(1):50-6.

155. Schumacher A, Peersen K, Sommervoll L, Seljeflot I, Arnesen H, Otterstad JE. Physical performance is associated with markers of vascular inflammation in patients with coronary heart disease. European Journal of Cardiovascular Prevention \& Rehabilitation. 2006;13(3):356-62.

156. Friesen CA. Operation Wellness: a university/community collaboration to enhance adult wellness. Family and Consumer Sciences Research Journal. 2010;39(2):152-60.

157. Monteagudo M, Rodriguez-Blanco T, Llagostera M, Valero C, Bayona X, Granollers S, et al. Effect of health professional education on outcomes of chronic obstructive pulmonary disease in primary care: a non-randomized clinical trial. Respirology. 2013;18(4):718-27.

158. Arikan I, Metintas S, Kalyoncu C. Application of Healthy Heart program in the two semi-rural areas in Eskisehir. Anadolu Kardiyol Derg. 2011;11(6):485-91.

159. Richardson G, van Woerden HC, Morgan L, Edwards R, Harries M, Hancock E, et al. Healthy hearts-a community-based primary prevention programme to reduce coronary heart disease. BMC Cardiovasc Disord. 2008;8:18.

160. Smith S, Yeomans D, Bushe CJ, Eriksson C, Harrison T, Holmes R, et al. A well-being programme in severe mental illness. Reducing risk for physical ill-health: a post-programme service evaluation at 2 
years. Eur Psychiatry. 2007;22(7):413-8.

161. Gamble JM, Hoang H, Eurich DT, Jindal KK, Senior PA. Patient-level evaluation of community-based, multifactorial intervention to prevent diabetic nephropathy in northern alberta, Canada. J Prim Care Community Health. 2012;3(2):111-9.

162. Sadeghi M, Aghdak P, Motamedi N, Tavassoli A, Kelishadi R, Sarrafzadegan N. Do intervention strategies of women healthy heart project (WHHP) impact on differently on working and housewives? ARYA atherosclerosis. 2011;6(4):129.

163. Lando HA, Pechacek TF, Pirie PL, Murray DM, Mittelmark MB, Lichtenstein E, et al. Changes in adult cigarette smoking in the Minnesota Heart Health Program. American Journal of Public Health. 1995;85(2):201-8.

164. Shin SA, Kim H, Lee K, Lin V, Liu G, Shin E. Effects of diabetic case management on knowledge, selfmanagement abilities, health behaviors, and health service utilization for diabetes in Korea. Yonsei Med J. 2015;56(1):244-52.

165. Schulz DN, Kremers SP, Vandelanotte C, van Adrichem MJ, Schneider F, Candel MJ, et al. Effects of a web-based tailored multiple-lifestyle intervention for adults: a two-year randomized controlled trial comparing sequential and simultaneous delivery modes. J Med Internet Res. 2014;16(1):e26.

166. Busch V, De Leeuw RJ, Schrijvers AJ. Results of a multibehavioral health-promoting school pilot intervention in a Dutch secondary school. J Adolesc Health. 2013;52(4):400-6.

167. Fernald DH, Dickinson LM, Froshaug DB, Balasubramanian BA, Holtrop JS, Krist AH, et al. Improving multiple health risk behaviors in primary care: lessons from the Prescription for Health Common Measures, Better Outcomes (COMBO) study. J Am Board Fam Med. 2012;25(5):701-11.

168. Cox CL, McLaughlin RA, Rai SN, Steen BD, Hudson MM. Adolescent survivors: a secondary analysis of a clinical trial targeting behavior change. Pediatr Blood Cancer. 2005;45(2):144-54.

169. Wills J, Kelly M. What works to encourage student nurses to adopt healthier lifestyles? Findings from an intervention study. Nurse Educ Today. 2017;48:180-4.

170. Dale H, Watson L, Adair P, Humphris G. Looked after young people: Reducing health inequalities through an evidence- and theory-informed intervention. Health Education Journal. 2016;75(7):811-22.

171. Zhou B, Chen K, Yu Y, Wang H, Zhang S, Zheng W. Individualized Health Intervention: Behavioral Change and Quality of Life in an Older Rural Chinese Population. Educational Gerontology. 2010;36(10-11):919-39.

172. Kadda O, Manginas A, Stavridis G, Balanos D, Kotiou M, Panagiotakos DB. Gender Analysis in the Outcomes of a Lifestyle Intervention Among Patients Who Had an Open Heart Surgery. Angiology. 2016;67(1):66-74.

173. Chander JSJU, Prakasam A, Kannan S, Kumar S, Tyagi MG. A study of pharmaceutical care impact on cardiovascular risk in diabetic and hypertensive patients.International journal of pharmaceutical sciences and research. 2013;4(8):3135. 
174. Schilling J, Faisst K, Lee C-Y, Candinas B, Gutzwiller F. The Check Bus Project and its effectiveness on health promotion at work. Journal of occupational health. 2005;47(2):136-42.

175. Park AH, Lee SJ, Oh SJ. The effects of a smoking cessation programme on health-promoting lifestyles and smoking cessation in smokers who had undergone percutaneous coronary intervention. Int J Nurs Pract. 2015;21(2):107-17.

176. Siddiqui FR, Shahid A. Promoting healthy workplaces Health pledges initiative at North Kirklees Primary Care Trust, NHS, England. Journal of the Pakistan Medical Association. 2012;62:1028-32.

177. Clouse ML, Mannino D, Curd PR. Investigation of the correlates and effectiveness of a prison-based wellness program. J Correct Health Care. 2012;18(3):184-97.

178. Niederhauser VP, Maddock J, LeDoux F, Arnold M. Building strong and ready army families: A multirisk reduction health promotion pilot study. Military Medicine. 2005;170(3):227-33.

179. Chaves G, Britez N, Munzinger J, Uhlmann L, Gonzalez G, Oviedo G, et al. Education to a Healthy Lifestyle Improves Symptoms and Cardiovascular Risk Factors - AsuRiesgo Study. Arq Bras Cardiol. 2015;104(5):347-55.

180. Kelishadi R, Sarrafzadegan N, Sadri GH, Pashmi R, Mohammadifard N, Tavasoli AA, et al. Short-term results of a community-based program on promoting healthy lifestyle for prevention and control of chronic diseases in a developing country setting: Isfahan Healthy Heart Program. Asia Pac J Public Health. 2011;23(4):518-33.

181. Byrne DW, Goetzel RZ, McGown PW, Holmes MC, Beckowski MS, Tabrizi MJ, et al. Seven-year trends in employee health habits from a comprehensive workplace health promotion program at Vanderbilt University. J Occup Environ Med. 2011;53(12):1372-81.

182. Goetzel RZ, Tabrizi M, Henke RM, Benevent R, Brockbank CV, Stinson K, et al. Estimating the return on investment from a health risk management program offered to small Colorado-based employers. $J$ Occup Environ Med. 2014;56(5):554-60.

\section{Tables}

Table 1: General Characteristics of 138 Included Articles 


\begin{tabular}{|c|c|c|}
\hline Category & & Count (percentage) \\
\hline \multicolumn{3}{|c|}{ Date of Publication } \\
\hline & 2011-2017 & $85(62 \%)$ \\
\hline & $2005-2010$ & $48(35)$ \\
\hline & $<2005$ & $5(4)$ \\
\hline \multicolumn{3}{|c|}{ Continent $^{a, b}$} \\
\hline & Africa & $2(1)$ \\
\hline & Asia & $18(13)$ \\
\hline & Australasia $^{\mathrm{c}}$ & $9(7)$ \\
\hline & Central/South America ${ }^{d}$ & $1(1)$ \\
\hline & North America ${ }^{\mathrm{e}}$ & $49(36)$ \\
\hline & Europe $^{\mathrm{f}}$ & $60(43)$ \\
\hline \multicolumn{3}{|c|}{ Quality Assessment ${ }^{b}$} \\
\hline & 4 stars & $66(48)$ \\
\hline & 3 stars & $59(43)$ \\
\hline & 2 stars & $13(9)$ \\
\hline \multicolumn{3}{|c|}{ Study Design ${ }^{a, b}$} \\
\hline & Cohort & $44(32)$ \\
\hline & Cross-sectional & $5(4)$ \\
\hline & Mixed method & $4(3)$ \\
\hline & Qualitative & $4(3)$ \\
\hline & Quasi-experimental & $23(17)$ \\
\hline & Randomized control trial & $63(46)$ \\
\hline & Other ${ }^{g}$ & $3(2)$ \\
\hline \multicolumn{3}{|c|}{ Theories of Behaviour Change Used ${ }^{a}$} \\
\hline & The Behaviour Change Approach & $2(1)$ \\
\hline & The Community Organization Approach & $2(1)$ \\
\hline & Goal-Systems Theory & $1(1)$ \\
\hline & Health Belief Model & $1(1)$ \\
\hline & Innovation-Diffusion Theory & $3(2)$ \\
\hline & Integrated Theory of Behaviour Change & $1(1)$ \\
\hline & Self-Regulation Theory & $2(1)$ \\
\hline
\end{tabular}




$\begin{array}{lc}\text { Social Cognitive Theory } & 8(6) \\ \text { Social-Ecological Theory } & 5(4) \\ \text { Social Learning Theory } & 6(4) \\ \text { Theory of Planned Behaviour } & 5(4) \\ \text { Transtheoretical Model } & 16(12)\end{array}$

a Total count sums to $>138$ as studies can fall into more than one category

${ }^{\mathrm{b}}$ Due to rounding, total percentages do not equal 100

${ }^{\mathrm{c}}$ China, India, Iran, Korea, Turkey, United Arab Emirates, Indonesia, Sri Lanka, Vietnam, Japan, Malaysia, Taiwan, Pakistan, Singapore, and Uzbekistan

d Brazil ,Paraguay

${ }^{\text {e }}$ Canada, Mexico, United States

${ }^{f}$ Denmark, Finland, Italy, Netherlands, Spain, Sweden, United Kingdom, France, Poland, Sweden, Croatia, Lithuania, Belgium, Greece, Portugal, Norway, Malta, Switzerland

g Case-control, case-study 


\begin{tabular}{|c|c|c|c|c|c|c|}
\hline Article & Location & $\begin{array}{l}\text { Context - } \\
\text { Setting }\end{array}$ & Target population & $\begin{array}{l}\text { Type of } \\
\text { prevention }\end{array}$ & $\begin{array}{l}\text { Activities } \\
\text { used in } \\
\text { intervention }\end{array}$ & $\begin{array}{l}\text { Mechanisms } \\
\text { used in } \\
\text { intervention }\end{array}$ \\
\hline \multicolumn{7}{|c|}{3 Behaviour Changes Targeted - ALCOHOL, PHYSICAL ACTIVITY, SMOKING } \\
\hline $\begin{array}{l}\text { Wang et al., } \\
2015 \text { [148] }\end{array}$ & Asia & $\begin{array}{l}\text { Community } \\
\text { Setting } \\
\text { Rural } \\
\text { Region }\end{array}$ & Adults with metabolic syndrome & Secondary & $\begin{array}{l}\text { Education } \\
\text { Group } \\
\text { Interactions } \\
\text { Tailored } \\
\text { Feedback }\end{array}$ & $\begin{array}{l}\text { Capability } \\
\text { Motivation } \\
\text { Opportunity }\end{array}$ \\
\hline $\begin{array}{l}\text { Mastrangelo } \\
\text { et al., } \\
2015 \text { [149] }\end{array}$ & Europe & $\begin{array}{l}\text { Workplace } \\
\text { Intervention }\end{array}$ & Adult/elderly male employees & $\begin{array}{l}\text { Primary } \\
\text { and } \\
\text { Secondary }\end{array}$ & $\begin{array}{l}\text { Counselling } \\
\text { Education }\end{array}$ & $\begin{array}{l}\text { Capability } \\
\text { Motivation }\end{array}$ \\
\hline $\begin{array}{l}\text { Jelinek et al., } \\
2014 \text { [69] }\end{array}$ & Australasia & $\begin{array}{l}\text { Low Socio- } \\
\text { Economic } \\
\text { Status }\end{array}$ & Adult/elderly cardiovascular patients & Secondary & $\begin{array}{l}\text { Counselling } \\
\text { Tailored } \\
\text { Feedback }\end{array}$ & $\begin{array}{l}\text { Capability } \\
\text { Opportunity }\end{array}$ \\
\hline $\begin{array}{l}\text { Saltychev et } \\
\text { al., } 2012 \text { [150] }\end{array}$ & Europe & $\begin{array}{l}\text { Clinical } \\
\text { Setting } \\
\text { Workplace } \\
\text { Intervention }\end{array}$ & Adult employees & Primary & $\begin{array}{l}\text { Group } \\
\text { Interactions }\end{array}$ & $\begin{array}{l}\text { Capability } \\
\text { Motivation }\end{array}$ \\
\hline $\begin{array}{l}\text { Kim et al., } \\
2016[72]\end{array}$ & North America & $\mathrm{N} / \mathrm{A}$ & Adult/elderly cardiovascular patients & Secondary & $\begin{array}{l}\text { Education } \\
\text { Social } \\
\text { Support }\end{array}$ & $\begin{array}{l}\text { Capability } \\
\text { Opportunity }\end{array}$ \\
\hline \multicolumn{7}{|c|}{3 Behaviour Changes Targeted - ALCOHOL, DIET, SMOKING } \\
\hline $\begin{array}{l}\text { Lopez et al., } \\
2007 \text { [102] }\end{array}$ & Europe & $\begin{array}{l}\text { Clinical } \\
\text { Setting }\end{array}$ & $\begin{array}{l}\text { Adult patients attending primary care } \\
\text { centers who have a first or second- } \\
\text { degree relative affected by cancer. }\end{array}$ & Primary & $\begin{array}{l}\text { Counselling } \\
\text { Education } \\
\text { Tailored } \\
\text { Feedback }\end{array}$ & $\begin{array}{l}\text { Capability } \\
\text { Motivation }\end{array}$ \\
\hline \multicolumn{7}{|c|}{3 Behaviour Changes Targeted - ALCOHOL, SMOKING, STRESS } \\
\hline $\begin{array}{l}\text { Laaksonen et } \\
\text { al., } 2013 \text { [151] }\end{array}$ & Europe & $\begin{array}{l}\text { Clinical } \\
\text { Setting }\end{array}$ & Adults & Secondary & $\begin{array}{l}\text { Education } \\
\text { Incentives } \\
\text { Tailored } \\
\text { Feedback } \\
\text { Pharmacolo- } \\
\text { gical Support }\end{array}$ & $\begin{array}{l}\text { Capability } \\
\text { Motivation } \\
\text { Opportunity }\end{array}$ \\
\hline \multicolumn{7}{|c|}{3 Behaviours Changes Targeted - DIET, PHYSICAL ACTIVITY, SMOKING } \\
\hline $\begin{array}{l}\text { Gomez-Pardo } \\
\text { et al., } \\
2016[74]\end{array}$ & Europe & $\mathrm{N} / \mathrm{A}$ & $\begin{array}{l}\text { Adults with at least } 1 \text { cardiovascular } \\
\text { risk factor }\end{array}$ & Primary & $\begin{array}{l}\text { Community } \\
\text { Organization } \\
\text { Education } \\
\text { Group } \\
\text { Interactions }\end{array}$ & $\begin{array}{l}\text { Capability } \\
\text { Opportunity }\end{array}$ \\
\hline
\end{tabular}




\begin{tabular}{|c|c|c|c|c|c|c|}
\hline & & & & & $\begin{array}{l}\text { Social } \\
\text { Support }\end{array}$ & \\
\hline $\begin{array}{l}\text { Ofori et al., } \\
2015 \text { [78] }\end{array}$ & Europe & $\begin{array}{l}\text { Clinical } \\
\text { Setting }\end{array}$ & Adult/elderly cardiovascular patients & $\begin{array}{l}\text { Primary } \\
\text { and } \\
\text { Secondary }\end{array}$ & $\begin{array}{l}\text { Counselling } \\
\text { Education } \\
\text { Group } \\
\text { Interactions } \\
\text { Motivational } \\
\text { Interviewing } \\
\text { Pharmacolo- } \\
\text { gical Support } \\
\text { Social } \\
\text { support } \\
\text { Tailored } \\
\text { Feedback }\end{array}$ & $\begin{array}{l}\text { Capability } \\
\text { Motivation } \\
\text { Opportunity }\end{array}$ \\
\hline $\begin{array}{l}\text { Saraf et al., } \\
2015 \text { [84] }\end{array}$ & Asia & $\begin{array}{l}\text { Rural } \\
\text { Region } \\
\text { School } \\
\text { Intervention }\end{array}$ & Adolescent students & Primary & $\begin{array}{l}\text { Community } \\
\text { Organization } \\
\text { Education } \\
\text { Incentives } \\
\text { Social } \\
\text { Support }\end{array}$ & $\begin{array}{l}\text { Capability } \\
\text { Motivation } \\
\text { Opportunity }\end{array}$ \\
\hline $\begin{array}{l}\text { Eckman et al., } \\
2012 \text { [152] }\end{array}$ & North America & $\begin{array}{l}\text { Clinical } \\
\text { Setting }\end{array}$ & Adult/elderly cardiovascular patients & Secondary & Education & Capability \\
\hline $\begin{array}{l}\text { Ruffin et al., } \\
2011 \text { [107] }\end{array}$ & North America & $\begin{array}{l}\text { Clinical } \\
\text { Setting }\end{array}$ & Adults in the general public & Primary & $\begin{array}{l}\text { Tailored } \\
\text { Feedback }\end{array}$ & Motivation \\
\hline $\begin{array}{l}\text { O'Brien et al., } \\
2010 \text { [153] }\end{array}$ & North America & $\begin{array}{l}\text { Community } \\
\text { Setting } \\
\text { School } \\
\text { Intervention }\end{array}$ & Adolescent students & Primary & $\begin{array}{l}\text { Community } \\
\text { Organization } \\
\text { Counselling } \\
\text { Education }\end{array}$ & $\begin{array}{l}\text { Capability } \\
\text { Opportunity }\end{array}$ \\
\hline $\begin{array}{l}\text { Wendel-Vos et } \\
\text { al., } 2009 \text { [154] }\end{array}$ & Europe & $\begin{array}{l}\text { Community } \\
\text { Setting } \\
\text { Low Socio- } \\
\text { Economic } \\
\text { Status }\end{array}$ & Adults in the general public & Primary & $\begin{array}{l}\text { Education } \\
\text { Group } \\
\text { Interactions } \\
\text { Mass Media } \\
\text { Campaigns }\end{array}$ & $\begin{array}{l}\text { Capability } \\
\text { Opportunity }\end{array}$ \\
\hline
\end{tabular}




\begin{tabular}{|c|c|c|c|c|c|c|}
\hline $\begin{array}{l}\text { Plescia et al., } \\
2008[81]\end{array}$ & North America & $\begin{array}{l}\text { Clinical } \\
\text { Setting } \\
\text { Community } \\
\text { Setting }\end{array}$ & $\begin{array}{l}\text { Adult/elderly urban, African American } \\
\text { community. }\end{array}$ & Primary & $\begin{array}{l}\text { Community } \\
\text { Organization } \\
\text { Education } \\
\text { Group } \\
\text { Interaction } \\
\text { Mass Media } \\
\text { Campaigns }\end{array}$ & $\begin{array}{l}\text { Capability } \\
\text { Opportunity }\end{array}$ \\
\hline $\begin{array}{l}\text { Schumacher } \\
\text { et al., } \\
2006[155]\end{array}$ & Europe & $\begin{array}{l}\text { Clinical } \\
\text { Setting }\end{array}$ & Adult/elderly cardiovascular patients & Secondary & $\begin{array}{l}\text { Counselling } \\
\text { Education } \\
\text { Group } \\
\text { Interactions }\end{array}$ & $\begin{array}{l}\text { Capability } \\
\text { Opportunity }\end{array}$ \\
\hline $\begin{array}{l}\text { Becker et al., } \\
2005 \text { [77] }\end{array}$ & North America & $\begin{array}{l}\text { Community } \\
\text { Setting }\end{array}$ & $\begin{array}{l}\text { African American adult siblings of } \\
\text { individuals hospitalized for coronary } \\
\text { heart disease }\end{array}$ & Primary & $\begin{array}{l}\text { Counseling } \\
\text { Incentives } \\
\text { Pharmacolo- } \\
\text { gical } \\
\text { Support }\end{array}$ & $\begin{array}{l}\text { Capability } \\
\text { Motivation } \\
\text { Opportunity }\end{array}$ \\
\hline $\begin{array}{l}\text { Friesen et al., } \\
2010[156]\end{array}$ & North America & $\begin{array}{l}\text { Community } \\
\text { Setting } \\
\text { School } \\
\text { Intervention } \\
\text { Workplace } \\
\text { Intervention } \\
\text { Rural } \\
\text { Region }\end{array}$ & Adults/elderly from general public & Primary & $\begin{array}{l}\text { Community } \\
\text { Organization } \\
\text { Education } \\
\text { Group } \\
\text { Interactions } \\
\text { Mass Media } \\
\text { Campaigns }\end{array}$ & $\begin{array}{l}\text { Capability } \\
\text { Opportunity }\end{array}$ \\
\hline $\begin{array}{l}\text { Shalaeva et } \\
\text { al., } 2017 \text { [67] }\end{array}$ & Asia & $\begin{array}{l}\text { Clinical } \\
\text { Setting }\end{array}$ & $\begin{array}{l}\text { Adult/elderly type } 2 \text { diabetes patients } \\
\text { having undergone trans-femoral } \\
\text { amputation (TFA) }\end{array}$ & Secondary & $\begin{array}{l}\text { Education } \\
\text { Incentives } \\
\text { Tailored } \\
\text { Feedback }\end{array}$ & $\begin{array}{l}\text { Capability } \\
\text { Opportunity }\end{array}$ \\
\hline $\begin{array}{l}\text { Monteagudo } \\
\text { et al., } \\
2013 \text { [157] }\end{array}$ & Europe & $\begin{array}{l}\text { Clinical } \\
\text { Setting }\end{array}$ & Adult/elderly patients with COPD & Secondary & $\begin{array}{l}\text { Counselling } \\
\text { Education } \\
\text { Motivational } \\
\text { Interviewing }\end{array}$ & $\begin{array}{l}\text { Capability } \\
\text { Motivation } \\
\text { Opportunity }\end{array}$ \\
\hline $\begin{array}{l}\text { Arikan et al., } \\
2011 \text { [158] }\end{array}$ & Asia & $\begin{array}{l}\text { Rural } \\
\text { Region }\end{array}$ & Adults from general public & Primary & $\begin{array}{l}\text { Education } \\
\text { Tailored } \\
\text { Feedback }\end{array}$ & Capability \\
\hline Richardson et & Europe & Community & Adults from general public & Primary & Education & Capability \\
\hline
\end{tabular}




\begin{tabular}{|c|c|c|c|c|c|c|}
\hline al., 2008 [159] & & Setting & & & $\begin{array}{l}\text { Tailored } \\
\text { Feedback }\end{array}$ & Opportunity \\
\hline $\begin{array}{l}\text { Naser et al., } \\
2008[103]\end{array}$ & Asia & $\begin{array}{l}\text { Clinical } \\
\text { Setting }\end{array}$ & Adult cardiovascular patients & Secondary & $\begin{array}{l}\text { Counselling } \\
\text { Education } \\
\text { Tailored } \\
\text { Feedback }\end{array}$ & $\begin{array}{l}\text { Capability } \\
\text { Motivation }\end{array}$ \\
\hline $\begin{array}{l}\text { Smith et al., } \\
2007 \text { [160] }\end{array}$ & Europe & $\begin{array}{l}\text { Clinical } \\
\text { Setting }\end{array}$ & Adults with severe mental illness & Secondary & $\begin{array}{l}\text { Education } \\
\text { Group } \\
\text { Interactions }\end{array}$ & $\begin{array}{l}\text { Capability } \\
\text { Opportunity }\end{array}$ \\
\hline $\begin{array}{l}\text { Dendana et } \\
\text { al., } 2017 \text { [73] }\end{array}$ & Africa & $\begin{array}{l}\text { School } \\
\text { Intervention }\end{array}$ & Adolescent students & Primary & $\begin{array}{l}\text { Education } \\
\text { Group } \\
\text { Interaction } \\
\text { Opinion } \\
\text { Leaders }\end{array}$ & $\begin{array}{l}\text { Capability } \\
\text { Opportunity }\end{array}$ \\
\hline $\begin{array}{l}\text { Gamble et al., } \\
2012[161]\end{array}$ & North America & $\begin{array}{l}\text { Clinical } \\
\text { Setting } \\
\text { Community } \\
\text { Setting }\end{array}$ & $\begin{array}{l}\text { Adult/elderly high-risk type } 2 \text { diabetic } \\
\text { patients with hypertension and/or } \\
\text { albuminuria }\end{array}$ & Tertiary & $\begin{array}{l}\text { Tailored } \\
\text { Feedback }\end{array}$ & Capability \\
\hline $\begin{array}{l}\text { Sadeghi et al., } \\
2011[162]\end{array}$ & Asia & $\begin{array}{l}\text { Community } \\
\text { Setting }\end{array}$ & $\begin{array}{l}\text { Adult/elderly females from general } \\
\text { public }\end{array}$ & Primary & $\begin{array}{l}\text { Education } \\
\text { Mass Media } \\
\text { Campaign }\end{array}$ & $\begin{array}{l}\text { Capability } \\
\text { Opportunity }\end{array}$ \\
\hline $\begin{array}{l}\text { Lando et al., } \\
1995 \text { [163] }\end{array}$ & North America & $\begin{array}{l}\text { Community } \\
\text { Setting } \\
\text { Workplace } \\
\text { Intervention }\end{array}$ & Adult/elderly from general public & Primary & $\begin{array}{l}\text { Community } \\
\text { Organization } \\
\text { Education } \\
\text { Mass Media } \\
\text { Campaign } \\
\text { Social } \\
\text { Support } \\
\text { Tailored } \\
\text { Feedback }\end{array}$ & $\begin{array}{l}\text { Capability } \\
\text { Motivation } \\
\text { Opportunity }\end{array}$ \\
\hline $\begin{array}{l}\text { Farquhar et } \\
\text { al., } 1990[41]\end{array}$ & North America & $\begin{array}{l}\text { Community } \\
\text { Setting } \\
\text { School } \\
\text { Intervention }\end{array}$ & Adults from general public & Primary & $\begin{array}{l}\text { Education } \\
\text { Incentives }\end{array}$ & $\begin{array}{l}\text { Capability } \\
\text { Motivation }\end{array}$ \\
\hline
\end{tabular}


3 Behaviours Changes Targeted - PHYSICAL ACTIVITY, SMOKING, STRESS

\begin{tabular}{|c|c|c|c|c|c|c|}
\hline $\begin{array}{l}\text { Baker et al., } \\
2015 \text { [12] }\end{array}$ & Europe & $\begin{array}{l}\text { Clinical } \\
\text { Setting }\end{array}$ & Adult/elderly cardiovascular patients & $\begin{array}{l}\text { Secondary } \\
\text { Prevention }\end{array}$ & Counselling & Capability \\
\hline \multicolumn{7}{|c|}{4 Behaviours Changes Targeted - ALCOHOL, DIET, PHYSICAL ACTIVITY, SMOKING } \\
\hline $\begin{array}{l}\text { Xavier et al., } \\
2016[71]\end{array}$ & Asia & $\begin{array}{l}\text { Clinical } \\
\text { Setting }\end{array}$ & Adult/elderly cardiovascular patients & Secondary & $\begin{array}{l}\text { Counselling } \\
\text { Education }\end{array}$ & $\begin{array}{l}\text { Capability } \\
\text { Opportunity }\end{array}$ \\
\hline $\begin{array}{l}\text { Shin et al., } \\
2015 \text { [164] }\end{array}$ & Asia & $\mathrm{N} / \mathrm{A}$ & Patients with diabetes & Secondary & Education & Capability \\
\hline $\begin{array}{l}\text { Van Den } \\
\text { Wijngaart et } \\
\text { al., } 2015 \text { [108] }\end{array}$ & Europe & $\begin{array}{l}\text { Clinical } \\
\text { Setting }\end{array}$ & Adult/elderly cardiovascular patients & Secondary & $\begin{array}{l}\text { Motivational } \\
\text { Interviewing } \\
\text { Tailored } \\
\text { Feedback }\end{array}$ & Motivation \\
\hline $\begin{array}{l}\text { Schulz et al., } \\
2014 \text { [165] }\end{array}$ & Europe & $\mathrm{N} / \mathrm{A}$ & Adults from general public & Primary & $\begin{array}{l}\text { Education } \\
\text { Tailored } \\
\text { feedback }\end{array}$ & $\begin{array}{l}\text { Capability } \\
\text { Motivation }\end{array}$ \\
\hline $\begin{array}{l}\text { Busch et al., } \\
2013 \text { [166] }\end{array}$ & Europe & $\begin{array}{l}\text { School } \\
\text { Intervention }\end{array}$ & Adolescent students & Primary & $\begin{array}{l}\text { Education } \\
\text { Group } \\
\text { Interactions }\end{array}$ & $\begin{array}{l}\text { Capability } \\
\text { Motivation } \\
\text { Opportunity }\end{array}$ \\
\hline $\begin{array}{l}\text { Fernald et al., } \\
2012 \text { [167] }\end{array}$ & North America & $\begin{array}{l}\text { Clinical } \\
\text { Settings }\end{array}$ & Adults from general public & Primary & $\begin{array}{l}\text { Community } \\
\text { Organization } \\
\text { Counselling } \\
\text { Education }\end{array}$ & $\begin{array}{l}\text { Capability } \\
\text { Opportunity }\end{array}$ \\
\hline $\begin{array}{l}\text { Tobari et al., } \\
2010 \text { [104] }\end{array}$ & Asia & $\begin{array}{l}\text { Clinical } \\
\text { Settings } \\
\text { Community } \\
\text { Settings }\end{array}$ & Adults/elderly cardiovascular patients & Secondary & $\begin{array}{l}\text { Counselling } \\
\text { Education } \\
\text { Tailored } \\
\text { Feedback }\end{array}$ & Capability \\
\hline $\begin{array}{l}\text { Holtrop et al., } \\
2008[76]\end{array}$ & North America & $\begin{array}{l}\text { Clinical } \\
\text { Setting }\end{array}$ & Adults from general public & Primary & $\begin{array}{l}\text { Counselling } \\
\text { Education } \\
\text { Motivational } \\
\text { Interviewing } \\
\text { Tailored } \\
\text { Feedback }\end{array}$ & $\begin{array}{l}\text { Capability } \\
\text { Motivation } \\
\text { Opportunity }\end{array}$ \\
\hline $\begin{array}{l}\text { Frank et al., } \\
2007 \text { [82] }\end{array}$ & North America & $\begin{array}{l}\text { School } \\
\text { Intervention }\end{array}$ & Adult students & Primary & $\begin{array}{l}\text { Counselling } \\
\text { Education }\end{array}$ & $\begin{array}{l}\text { Capability } \\
\text { Opportunity }\end{array}$ \\
\hline $\begin{array}{l}\text { Cox et al., } \\
2005 \text { [168] }\end{array}$ & North America & $\begin{array}{l}\text { Clinical } \\
\text { Setting }\end{array}$ & Adult cancer patients & Tertiary & Counselling & Capability \\
\hline
\end{tabular}

Page $38 / 50$ 


\begin{tabular}{|c|c|c|c|c|c|c|}
\hline & & & & & Education & Motivation \\
\hline $\begin{array}{l}\text { Wills et al., } \\
2017 \text { [169] }\end{array}$ & Europe & $\begin{array}{l}\text { School } \\
\text { Intervention }\end{array}$ & Adult students & Primary & Education & Capability \\
\hline $\begin{array}{l}\text { Dale et al., } \\
2016[170]\end{array}$ & Europe & $\begin{array}{l}\text { School } \\
\text { Intervention }\end{array}$ & Disadvantaged adults/adoles-cents & Primary & $\begin{array}{l}\text { Counselling } \\
\text { Group } \\
\text { Interactions } \\
\text { Motivational } \\
\text { Interviewing } \\
\text { Social } \\
\text { Support } \\
\text { Tailored } \\
\text { Feedback }\end{array}$ & $\begin{array}{l}\text { Capability } \\
\text { Motivation }\end{array}$ \\
\hline $\begin{array}{l}\text { Zhou et al., } \\
2010[171]\end{array}$ & Asia & $\begin{array}{l}\text { Rural } \\
\text { Region }\end{array}$ & $\begin{array}{l}\text { Rural Chinese, Asian/Pacific Islander } \\
\text { adult/elderly }\end{array}$ & $\begin{array}{l}\text { Primary } \\
\text { and } \\
\text { Secondary }\end{array}$ & $\begin{array}{l}\text { Counselling } \\
\text { Motivational } \\
\text { Interviewing } \\
\text { Social } \\
\text { Support } \\
\text { Tailored } \\
\text { Feedback }\end{array}$ & $\begin{array}{l}\text { Capability } \\
\text { Motivation } \\
\text { Opportunity }\end{array}$ \\
\hline $\begin{array}{l}\text { Kadda et al., } \\
2016[172]\end{array}$ & Europe & $\begin{array}{l}\text { Clinical } \\
\text { Setting }\end{array}$ & Adult/elderly cardiovascular patients & Tertiary & $\begin{array}{l}\text { Counselling } \\
\text { Education } \\
\text { Social } \\
\text { Support }\end{array}$ & $\begin{array}{l}\text { Capability } \\
\text { Motivation } \\
\text { Opportunity }\end{array}$ \\
\hline $\begin{array}{l}\text { Chander et } \\
\text { al., } 2013 \text { [173] }\end{array}$ & Asia & $\begin{array}{l}\text { Clinical } \\
\text { Setting } \\
\text { Low Socio- } \\
\text { Economic } \\
\text { Status }\end{array}$ & $\begin{array}{l}\text { Adult/elderly cardiovascular patients } \\
\text { with diabetes }\end{array}$ & Secondary & $\begin{array}{l}\text { Counselling } \\
\text { Education } \\
\text { Group } \\
\text { Interactions }\end{array}$ & Capability \\
\hline $\begin{array}{l}\text { Schilling et } \\
\text { al., } 2005 \text { [174] }\end{array}$ & Europe & $\begin{array}{l}\text { Workplace } \\
\text { Intervention }\end{array}$ & Adult employees & Primary & $\begin{array}{l}\text { Education } \\
\text { Tailored } \\
\text { Feedback }\end{array}$ & Capability \\
\hline \multicolumn{7}{|c|}{4 Behaviours Changes Targeted - DIET, PHYSICAL ACTIVITY, SMOKING, STRESS } \\
\hline $\begin{array}{l}\text { Park et al., } \\
2015 \text { [175] }\end{array}$ & Asia & $\mathrm{N} / \mathrm{A}$ & $\begin{array}{l}\text { Asian/Pacific Islanders adult/elderly } \\
\text { cardiovascular patients }\end{array}$ & Secondary & $\begin{array}{l}\text { Counselling } \\
\text { Education }\end{array}$ & $\begin{array}{l}\text { Capability } \\
\text { Motivation }\end{array}$ \\
\hline
\end{tabular}




\begin{tabular}{|c|c|c|c|c|c|c|}
\hline & & & & & $\begin{array}{l}\text { Incentives } \\
\text { Social } \\
\text { Support }\end{array}$ & Opportunity \\
\hline $\begin{array}{l}\text { Gibson et al., } \\
2014 \text { [70] }\end{array}$ & Europe & $\begin{array}{l}\text { Community } \\
\text { Setting }\end{array}$ & $\begin{array}{l}\text { Adults with diabetes and } 2 \text { other risk } \\
\text { factors (smoking, hypertension or } \\
\text { dyslipidaemia) }\end{array}$ & Secondary & $\begin{array}{l}\text { Education } \\
\text { Group } \\
\text { Interaction } \\
\text { Motivational } \\
\text { Interviewing } \\
\text { Social } \\
\text { Support } \\
\text { Tailored } \\
\text { Feedback } \\
\text { Pharmacolo- } \\
\text { gical Support }\end{array}$ & $\begin{array}{l}\text { Capability } \\
\text { Motivation } \\
\text { Opportunity }\end{array}$ \\
\hline $\begin{array}{l}\text { Siddiqui et al., } \\
2012 \text { [176] }\end{array}$ & Europe & $\begin{array}{l}\text { Workplace } \\
\text { Intervention }\end{array}$ & Adult employees & Primary & $\begin{array}{l}\text { Counselling } \\
\text { Incentives } \\
\text { Motivational } \\
\text { Interviewing }\end{array}$ & $\begin{array}{l}\text { Capability } \\
\text { Opportunity }\end{array}$ \\
\hline $\begin{array}{l}\text { Clouse et al., } \\
2012 \text { [177] }\end{array}$ & North America & $\begin{array}{l}\text { Community } \\
\text { Setting } \\
\text { Prison/Jail }\end{array}$ & $\begin{array}{l}\text { Adult incarcerated males (residents of a } \\
\text { correctional substance abuse program) }\end{array}$ & Primary & $\begin{array}{l}\begin{array}{l}\text { Community } \\
\text { Organization }\end{array} \\
\text { Education } \\
\text { Group } \\
\text { Interactions } \\
\text { Opinion } \\
\text { Leaders } \\
\text { Mass Media } \\
\text { Campaigns }\end{array}$ & $\begin{array}{l}\text { Capability } \\
\text { Motivation } \\
\text { Opportunity }\end{array}$ \\
\hline $\begin{array}{l}\text { Jolly et al., } \\
2007 \text { [83] }\end{array}$ & Europe & $\begin{array}{l}\text { Clinical } \\
\text { Setting } \\
\text { Low Socio- } \\
\text { Economic } \\
\text { Status }\end{array}$ & Adult/elderly cardiovascular patients & Secondary & $\begin{array}{l}\text { Counselling } \\
\text { Education }\end{array}$ & $\begin{array}{l}\text { Capability } \\
\text { Motivation } \\
\text { Opportunity }\end{array}$ \\
\hline $\begin{array}{l}\text { Long et al., } \\
2010 \text { [66] }\end{array}$ & North America & $\begin{array}{l}\text { Workplace } \\
\text { Intervention }\end{array}$ & Adult employees & Primary & $\begin{array}{l}\text { Counselling } \\
\text { Education }\end{array}$ & $\begin{array}{l}\text { Capability } \\
\text { Motivation } \\
\text { Opportunity }\end{array}$ \\
\hline
\end{tabular}




\begin{tabular}{|c|c|c|c|c|c|c|}
\hline & & & & & $\begin{array}{l}\text { Group } \\
\text { Interactions } \\
\text { Incentives } \\
\text { Pharmacolo- } \\
\text { gical Support } \\
\text { Opinion } \\
\text { Leaders } \\
\text { Tailored } \\
\text { Feedback }\end{array}$ & \\
\hline $\begin{array}{l}\text { Niederhauser } \\
\text { et al., } \\
2005 \text { [178] }\end{array}$ & North America & $\begin{array}{l}\text { Community } \\
\text { Setting }\end{array}$ & $\begin{array}{l}\text { Active duty infantry soldiers and their } \\
\text { spouses }\end{array}$ & Primary & $\begin{array}{l}\text { Community } \\
\text { Organization } \\
\text { Counselling } \\
\text { Education } \\
\text { Incentives }\end{array}$ & $\begin{array}{l}\text { Capability } \\
\text { Motivation } \\
\text { Opportunity }\end{array}$ \\
\hline $\begin{array}{l}\text { White et al., } \\
2015 \text { [105] }\end{array}$ & North America & $\begin{array}{l}\text { Workplace } \\
\text { Intervention }\end{array}$ & Adult employees & Primary & $\begin{array}{l}\text { Counselling } \\
\text { Education } \\
\text { Tailored } \\
\text { Feedback }\end{array}$ & $\begin{array}{l}\text { Capability } \\
\text { Motivation }\end{array}$ \\
\hline $\begin{array}{l}\text { Chaves et al., } \\
2015 \text { [179] }\end{array}$ & $\begin{array}{l}\text { Central } \\
\text { America/South } \\
\text { America/Caribbean }\end{array}$ & $\begin{array}{l}\text { Clinical } \\
\text { Setting }\end{array}$ & Adult/elderly from general public & $\begin{array}{l}\text { Primary } \\
\text { and } \\
\text { Secondary }\end{array}$ & $\begin{array}{l}\text { Counselling } \\
\text { Education } \\
\text { Social } \\
\text { Support }\end{array}$ & Capability \\
\hline $\begin{array}{l}\text { Kelishadi et } \\
\text { al., } 2011[180]\end{array}$ & Asia & $\begin{array}{l}\text { Clinical } \\
\text { setting } \\
\text { Community } \\
\text { Setting } \\
\text { School } \\
\text { Intervention }\end{array}$ & Adults from general public & $\begin{array}{l}\text { Primary } \\
\text { and } \\
\text { Secondary }\end{array}$ & $\begin{array}{l}\text { Community } \\
\text { Organization } \\
\text { Education } \\
\text { Mass Media } \\
\text { Campaigns } \\
\text { Opinion } \\
\text { Leaders }\end{array}$ & $\begin{array}{l}\text { Capability } \\
\text { Opportunity }\end{array}$ \\
\hline $\begin{array}{l}\text { Puska et al., } \\
1985 \text { [40] }\end{array}$ & Europe & $\begin{array}{l}\text { Clinical } \\
\text { Setting } \\
\text { Community } \\
\text { Setting } \\
\text { School } \\
\text { Intervention }\end{array}$ & Adults from general public & Primary & $\begin{array}{l}\text { Community } \\
\text { Organization } \\
\text { Education } \\
\text { Mass Media } \\
\text { Campaigns }\end{array}$ & $\begin{array}{l}\text { Capability } \\
\text { Motivation } \\
\text { Opportunity }\end{array}$ \\
\hline
\end{tabular}




\begin{tabular}{|c|c|c|c|c|c|c|}
\hline & & & & & $\begin{array}{l}\text { Opinion } \\
\text { Leaders } \\
\text { Social } \\
\text { Support }\end{array}$ & \\
\hline \multicolumn{7}{|c|}{5 Behaviours Changes Targeted- ALCOHOL, DIET, PHYSICAL ACTIVITY, SMOKING, STRESS } \\
\hline $\begin{array}{l}\text { Baker et al., } \\
2009[75]\end{array}$ & Australasia & $\mathrm{N} / \mathrm{A}$ & $\begin{array}{l}\text { Adult smokers with non-acute } \\
\text { psychiatric disorders }\end{array}$ & Primary & $\begin{array}{l}\text { Counselling } \\
\text { Education } \\
\text { Incentives } \\
\text { Motivational } \\
\text { Interviewing } \\
\text { Pharmacolo- } \\
\text { gical Support } \\
\text { Tailored } \\
\text { Feedback }\end{array}$ & $\begin{array}{l}\text { Capability } \\
\text { Motivation } \\
\text { Opportunity }\end{array}$ \\
\hline $\begin{array}{l}\text { Byrne et al., } \\
2011[181]\end{array}$ & North America & $\begin{array}{l}\text { Workplace } \\
\text { Intervention }\end{array}$ & Adult/elderly employees & Primary & $\begin{array}{l}\text { Community } \\
\text { Organization } \\
\text { Counselling } \\
\text { Education } \\
\text { Group } \\
\text { Interactions } \\
\text { Incentives } \\
\text { Tailored } \\
\text { Feedback }\end{array}$ & $\begin{array}{l}\text { Capability } \\
\text { Motivation } \\
\text { Opportunity }\end{array}$ \\
\hline $\begin{array}{l}\text { Henke et al., } \\
2011[65]\end{array}$ & North America & $\begin{array}{l}\text { Workplace } \\
\text { Intervention }\end{array}$ & Adult employees & Primary & $\begin{array}{l}\text { Community } \\
\text { Organization } \\
\text { Incentives } \\
\text { Tailored } \\
\text { Feedback }\end{array}$ & $\begin{array}{l}\text { Capability } \\
\text { Motivation } \\
\text { Opportunity }\end{array}$ \\
\hline $\begin{array}{l}\text { Goetzel et al., } \\
2014 \text { [182] }\end{array}$ & North America & $\begin{array}{l}\text { Workplace } \\
\text { Intervention }\end{array}$ & Adult employees & Primary & $\begin{array}{l}\text { Community } \\
\text { Organization } \\
\text { Counselling } \\
\text { Education } \\
\text { Tailored } \\
\text { Feedback }\end{array}$ & $\begin{array}{l}\text { Capability } \\
\text { Motivation }\end{array}$ \\
\hline \multicolumn{7}{|c|}{6 Behaviours Changes Targeted - ALCOHOL, DIET, PHYSICAL ACTIVITY, SLEEP, SMOKING, STRESS } \\
\hline Kuehl et al., & North America & Workplace & Adult employees & Primary & Education & Capability \\
\hline
\end{tabular}




\begin{tabular}{|l|l|l|l|l|l|l|l|} 
2016 [68] & Intervention & & & Group & Interactions \\
& & & & Social & Support \\
\hline
\end{tabular}

${ }^{\text {a }}$ N/A stands for not available. There was no information available from the article for the specific category.

Table 3: Interventions with a Four Star Quality Rating and Statistical Analyses That Reported Using "Opportunity". 


\begin{tabular}{|c|c|c|}
\hline Mechanism $^{\mathrm{a}}$ & $\begin{array}{l}\text { Total number of interventions } \\
\text { using the C-M-O }\end{array}$ & $\begin{array}{l}\text { Number of interventions using the C-M-O that report } \\
\text { improvement in smoking cessation outcome }\end{array}$ \\
\hline \multicolumn{3}{|l|}{ CONTEXT } \\
\hline \multicolumn{3}{|l|}{ NORTH AMERICA } \\
\hline Opportunity & $\begin{array}{l}11 \\
{[60,61,65,66,68,72,76,77,81,} \\
82,85]\end{array}$ & $\begin{array}{l}8(73 \%) \\
{[65,66,68,72,76,77,81,82]}\end{array}$ \\
\hline Opportunity - Access & $\begin{array}{l}7 \\
{[60,65,66,76,77,81,82]}\end{array}$ & $\begin{array}{l}6(86 \%) \\
{[65,66,76,77,81,82]}\end{array}$ \\
\hline $\begin{array}{l}\text { Opportunity - Changing Physical } \\
\text { and/or Social Environment }\end{array}$ & $\begin{array}{l}6 \\
{[61,65,66,68,81,82]}\end{array}$ & $\begin{array}{l}5(83 \%) \\
{[65,66,68,81,82]}\end{array}$ \\
\hline Opportunity - Social Support & $\begin{array}{l}6 \\
{[60,65,66,68,72,76]}\end{array}$ & $\begin{array}{l}5(83 \%) \\
{[65,66,68,72,76]}\end{array}$ \\
\hline \multicolumn{3}{|l|}{ ASIA } \\
\hline Opportunity - Social Support & $\begin{array}{l}3 \\
{[67,71,80]}\end{array}$ & $\begin{array}{l}2(67 \%) \\
{[67,71]}\end{array}$ \\
\hline \multicolumn{3}{|l|}{ CLINICAL SETTING } \\
\hline Opportunity - Access & $\begin{array}{l}3 \\
{[76,81,83]}\end{array}$ & $\begin{array}{l}3(100 \%) \\
{[76,81,83]}\end{array}$ \\
\hline \multicolumn{3}{|l|}{ COMMUNITY BASED CARE } \\
\hline Opportunity & $\begin{array}{l}5 \\
{[40,60,70,77,81]}\end{array}$ & $\begin{array}{l}4(80 \%) \\
{[40,70,77,81]}\end{array}$ \\
\hline Opportunity - Access & $\begin{array}{l}4 \\
{[60,70,77,81]}\end{array}$ & $\begin{array}{l}3(75 \%) \\
{[70,77,81]}\end{array}$ \\
\hline \multicolumn{3}{|l|}{ WORKPLACE } \\
\hline Opportunity - Access & $\begin{array}{l}3 \\
{[62,65,66]}\end{array}$ & $\begin{array}{l}2(67 \%) \\
{[65,66]}\end{array}$ \\
\hline Opportunity - Social Support & $\begin{array}{l}3 \\
{[65,66,68]}\end{array}$ & $\begin{array}{l}3(100 \%) \\
{[65,66,68]}\end{array}$ \\
\hline \multicolumn{3}{|l|}{ SCHOOLS } \\
\hline Opportunity & $\begin{array}{l}4 \\
{[40,73,82,84]}\end{array}$ & $\begin{array}{l}4(100 \%) \\
{[40,73,82,84]}\end{array}$ \\
\hline $\begin{array}{l}\text { Opportunity - Changing Physical } \\
\text { and/or Social Environment }\end{array}$ & $\begin{array}{l}4 \\
{[40,73,82,84]}\end{array}$ & $\begin{array}{l}4(100 \%) \\
{[40,73,82,84]}\end{array}$ \\
\hline \multicolumn{3}{|l|}{ TARGET POPULATION } \\
\hline \multicolumn{3}{|l|}{ PRIMARY PREVENTION } \\
\hline Opportunity & $\begin{array}{l}20 \\
{[40,56,58,59,61,62,65,66,68,} \\
73-79,81,82,84,86]\end{array}$ & $\begin{array}{l}13(65 \%) \\
{[40,65,66,68,73-78,81,82,84]}\end{array}$ \\
\hline Opportunity - Access & 8 & $7(88 \%)$ \\
\hline
\end{tabular}




\begin{tabular}{|c|c|c|}
\hline & {$[62,65,66,76,77,81,82,84]$} & {$[65,66,76,77,81,82,84]$} \\
\hline $\begin{array}{l}\text { Opportunity - Changing Physical } \\
\text { and/or Social Environment }\end{array}$ & $\begin{array}{l}11 \\
{[40,59,61,62,65,66,68,73,81,} \\
82,84]\end{array}$ & $\begin{array}{l}8(73 \%) \\
{[40,65,66,68,73,81,82,84]}\end{array}$ \\
\hline Opportunity - Social Support & $\begin{array}{l}9 \\
{[65,66,68,74-76,78,79,86]}\end{array}$ & $\begin{array}{l}7(78 \%) \\
{[65,66,68,74-76,78]}\end{array}$ \\
\hline \multicolumn{3}{|l|}{ SECONDARY PREVENTION } \\
\hline Opportunity - Access & $\begin{array}{l}4 \\
{[60,69,70,83]}\end{array}$ & $\begin{array}{l}3(75 \%) \\
{[69,70,83]}\end{array}$ \\
\hline \multicolumn{3}{|c|}{ TYPE OF MODIFIABLE RISK BEHAVIOUR INTERVENTION ADDRESSED } \\
\hline \multicolumn{3}{|l|}{ ALCOHOL } \\
\hline Opportunity & $\begin{array}{l}13 \\
{[56,58-60,63,65,68,69,71,72,} \\
75,76,82]\end{array}$ & $\begin{array}{l}8(62 \%) \\
{[65,68,69,71,72,75,76,82]}\end{array}$ \\
\hline Opportunity - Access & $\begin{array}{l}5 \\
{[60,65,69,76,82]}\end{array}$ & $\begin{array}{l}4(80 \%) \\
{[65,69,76,82]}\end{array}$ \\
\hline $\begin{array}{l}\text { Opportunity - Changing Physical } \\
\text { and/or Social Environment }\end{array}$ & $\begin{array}{l}4 \\
{[59,65,68,82]}\end{array}$ & $\begin{array}{l}3(75 \%) \\
{[65,68,82]}\end{array}$ \\
\hline Opportunity - Social Support & $\begin{array}{l}7 \\
{[60,65,68,71,72,75,76]}\end{array}$ & $\begin{array}{l}6(86 \%) \\
{[65,68,71,72,75,76]}\end{array}$ \\
\hline \multicolumn{3}{|l|}{ DIET } \\
\hline Opportunity - Access & $\begin{array}{l}11 \\
{[60,62,65,66,70,76,77,81-84]}\end{array}$ & $\begin{array}{l}9(82 \%) \\
{[65,66,70,76,77,81-84]}\end{array}$ \\
\hline $\begin{array}{l}\text { Opportunity - Changing Physical } \\
\text { and/or Social Environment }\end{array}$ & $\begin{array}{l}11 \\
{[40,59,61,62,65,66,68,73,81,} \\
82,84]\end{array}$ & $\begin{array}{l}8(73 \%) \\
{[40,65,66,68,73,81,82,84]}\end{array}$ \\
\hline Opportunity - Social Support & $\begin{array}{l}14 \\
{[60,64-68,71,74-76,78-80,86]}\end{array}$ & $\begin{array}{l}9(64 \%) \\
{[65-68,71,74-76,78]}\end{array}$ \\
\hline \multicolumn{3}{|l|}{ PHYSICAL ACTIVITY } \\
\hline Opportunity - Access & $\begin{array}{l}12 \\
{[60,62,65,66,69,70,76,77,81-} \\
84]\end{array}$ & $\begin{array}{l}10(83 \%) \\
{[65,66,69,70,76,77,81-84]}\end{array}$ \\
\hline $\begin{array}{l}\text { Opportunity - Changing Physical } \\
\text { and/or Social Environment }\end{array}$ & $\begin{array}{l}11 \\
{[40,59,61,62,65,66,68,73,81,} \\
82,84]\end{array}$ & $\begin{array}{l}8(73 \%) \\
{[40,65,66,68,73,81,82,84]}\end{array}$ \\
\hline Opportunity - Social Support & $\begin{array}{l}15 \\
{[60,64-68,71,72,74-76,78-80,86]}\end{array}$ & $\begin{array}{l}10(67 \%) \\
{[65-68,71,72,74-76,78]}\end{array}$ \\
\hline \multicolumn{3}{|l|}{ STRESS } \\
\hline Opportunity & $\begin{array}{l}10 \\
{[40,59,60,65,66,68,70,75,83,} \\
85]\end{array}$ & $\begin{array}{l}7(70 \%) \\
{[40,65,66,68,70,75,83]}\end{array}$ \\
\hline Opportunity - Access & 5 & $4(80 \%)$ \\
\hline
\end{tabular}




\begin{tabular}{|c|c|c|}
\hline & {$[60,65,66,70,83]$} & {$[65,66,70,83]$} \\
\hline $\begin{array}{l}\text { Opportunity - Changing Physical } \\
\text { and/or Social Environment }\end{array}$ & $\begin{array}{l}5 \\
{[40,59,65,66,68]}\end{array}$ & $\begin{array}{l}4(80 \%) \\
{[40,65,66,68]}\end{array}$ \\
\hline Opportunity - Social Support & $\begin{array}{l}5 \\
{[60,65,66,68,75]}\end{array}$ & $\begin{array}{l}4(80 \%) \\
{[65,66,68,75]}\end{array}$ \\
\hline \multicolumn{3}{|c|}{ NUMBER OF MODIFIABLE RISK BEHAVIOURS } \\
\hline \multicolumn{3}{|l|}{3 BEHAVIOURS } \\
\hline Opportunity - Access & $\begin{array}{l}5 \\
{[62,69,77,81,84]}\end{array}$ & $\begin{array}{l}4(80 \%) \\
{[69,77,81,84]}\end{array}$ \\
\hline $\begin{array}{l}\text { Opportunity - Changing Physical } \\
\text { and/or Social Environment }\end{array}$ & $\begin{array}{l}5 \\
{[61,62,73,81,84]}\end{array}$ & $\begin{array}{l}3(60 \%) \\
{[73,81,84]}\end{array}$ \\
\hline \multicolumn{3}{|l|}{4 BEHAVIOURS } \\
\hline Opportunity & $\begin{array}{l}11 \\
{[40,56,58,63,66,70,71,76,82,} \\
83,85]\end{array}$ & $\begin{array}{l}7(64 \%) \\
{[40,66,70,71,76,82,83]}\end{array}$ \\
\hline Opportunity - Access & $\begin{array}{l}5 \\
{[66,70,76,82,83]}\end{array}$ & $\begin{array}{l}5(100 \%) \\
{[66,70,76,82,83]}\end{array}$ \\
\hline $\begin{array}{l}\text { Opportunity - Changing Physical } \\
\text { and/or Social Environment }\end{array}$ & $\begin{array}{l}3 \\
{[40,66,82]}\end{array}$ & $\begin{array}{l}3(100 \%) \\
{[40,66,82]}\end{array}$ \\
\hline Opportunity - Social Support & $\begin{array}{l}3 \\
{[66,71,76]}\end{array}$ & $\begin{array}{l}3(100 \%) \\
{[66,71,76]}\end{array}$ \\
\hline \multicolumn{3}{|l|}{5 BEHAVIOURS } \\
\hline Opportunity - Social Support & $\begin{array}{l}3 \\
{[60,65,75]}\end{array}$ & $\begin{array}{l}2(67 \%) \\
{[65,75]}\end{array}$ \\
\hline
\end{tabular}

a The mechanisms within these interventions may not be exclusively for addressing smoking behaviour. It could be part of the overall intervention or for other risk behaviours within that intervention.

b This category examines interventions that include the specific risk behaviour (i.e. alcohol) as one of the targeted behaviours.

Table 4: Interventions with a Four Star Quality Rating and Statistical Analyses That Reported Using "Capability". 


\begin{tabular}{|c|c|c|}
\hline Mechanism $^{\mathrm{a}}$ & Total number of interventions using the C-M-O & $\begin{array}{l}\text { Number of interventions using the C-M-O that report } \\
\text { improvement in smoking cessation outcome }\end{array}$ \\
\hline \multicolumn{3}{|l|}{ CONTEXT } \\
\hline \multicolumn{3}{|l|}{ NORTH AMERICA } \\
\hline Capability - Empowerment & $\begin{array}{l}3 \\
{[65,97,99]}\end{array}$ & $\begin{array}{l}1(33 \%) \\
{[65]}\end{array}$ \\
\hline \multicolumn{3}{|l|}{ EUROPE } \\
\hline Capability & $\begin{array}{l}19 \\
{[40,56-58,64,70,74,78,79,83,86,88-92,94} \\
95,102]\end{array}$ & $\begin{array}{l}6(32 \%) \\
{[40,70,74,78,83,102]}\end{array}$ \\
\hline $\begin{array}{l}\text { Capability - Beliefs about } \\
\text { Interventions }\end{array}$ & $\begin{array}{l}3 \\
{[64,89,90]}\end{array}$ & $0(0 \%)$ \\
\hline Capability- Capacity to Plan & $\begin{array}{l}14 \\
{[40,56,57,64,74,78,79,83,86,88,90,92,95,} \\
102]\end{array}$ & $\begin{array}{l}5(36 \%) \\
{[40,74,78,83,102]}\end{array}$ \\
\hline Capability- Empowerment & $\begin{array}{l}6 \\
{[74,79,90,92,94,95]}\end{array}$ & $\begin{array}{l}1(17 \%) \\
{[74]}\end{array}$ \\
\hline $\begin{array}{l}\text { Capability - Enhance Knowledge } \\
\text { and Skills of Individual }\end{array}$ & $\begin{array}{l}18 \\
{[40,56-58,70,74,78,79,83,86,88-92,94,95,} \\
102]\end{array}$ & $\begin{array}{l}6(33 \%) \\
{[40,70,74,78,83,102]}\end{array}$ \\
\hline \multicolumn{3}{|l|}{ ASIA } \\
\hline Capability & $\begin{array}{l}8 \\
{[59,63,67,71,80,84,103,104]}\end{array}$ & $\begin{array}{l}5(63 \%) \\
{[67,71,84,103,104]}\end{array}$ \\
\hline Capability - Capacity to Plan & $\begin{array}{l}5 \\
{[63,71,80,103,104]}\end{array}$ & $\begin{array}{l}3(60 \%) \\
{[71,103,104]}\end{array}$ \\
\hline $\begin{array}{l}\text { Capability - Enhance Knowledge } \\
\text { and Skills of Individual }\end{array}$ & $\begin{array}{l}8 \\
{[59,63,67,71,80,84,103,104]}\end{array}$ & $\begin{array}{l}5(63 \%) \\
{[67,71,84,103,104]}\end{array}$ \\
\hline \multicolumn{3}{|l|}{ AUSTRALASIA } \\
\hline Capability & $\begin{array}{l}5 \\
{[12,69,75,87,98]}\end{array}$ & $\begin{array}{l}2(40 \%) \\
{[69,75]}\end{array}$ \\
\hline Capability - Capacity to Plan & $\begin{array}{l}4 \\
{[12,75,87,98]} \\
\end{array}$ & $\begin{array}{l}1(25 \%) \\
{[75]}\end{array}$ \\
\hline \multicolumn{3}{|l|}{ CLINICAL SETTING } \\
\hline Capability & $\begin{array}{l}27 \\
{[12,40,43,57,58,64,67,71,76,78-81,83,85} \\
86,89,91-95,99,100,102-104]\end{array}$ & $\begin{array}{l}10(37 \%) \\
{[40,67,71,76,78,81,83,102-104]}\end{array}$ \\
\hline $\begin{array}{l}\text { Capability - Beliefs about } \\
\text { Intervention }\end{array}$ & $\begin{array}{l}3 \\
{[64,71,89]}\end{array}$ & $\begin{array}{l}1(33 \%) \\
{[71]}\end{array}$ \\
\hline Capability - Capacity to Plan & $\begin{array}{l}20 \\
{[12,40,43,57,64,71,76,78-80,83,86,92,93} \\
95,99,100,102-104]\end{array}$ & $\begin{array}{l}8(40 \%) \\
{[40,71,76,78,83,102-104]}\end{array}$ \\
\hline Capability - Empowerment & $\begin{array}{l}7 \\
{[67,71,79,92,94,95,99]} \\
\end{array}$ & $\begin{array}{l}2(29 \%) \\
{[67,71]}\end{array}$ \\
\hline \multicolumn{3}{|l|}{ COMMUNITY BASED CARE } \\
\hline Capability & $\begin{array}{l}7 \\
{[40,60,70,77,81,100,104]}\end{array}$ & $\begin{array}{l}5(71 \%) \\
{[40,70,77,81,104]}\end{array}$ \\
\hline Capability - Capacity to Plan & $\begin{array}{l}5 \\
{[40,60,77,100,104]}\end{array}$ & $\begin{array}{l}3(60 \%) \\
{[40,77,104]}\end{array}$ \\
\hline
\end{tabular}




\begin{tabular}{|c|c|c|}
\hline $\begin{array}{l}\text { Capability - Enhance Knowledge } \\
\text { and Skills of individual }\end{array}$ & $\begin{array}{l}6 \\
{[40,60,70,77,81,104]}\end{array}$ & $\begin{array}{l}5(83 \%) \\
{[40,70,77,81,104]}\end{array}$ \\
\hline \multicolumn{3}{|l|}{ WORKPLACE } \\
\hline Capability - Capacity to Plan & $\begin{array}{l}4 \\
{[65,66,68,97]}\end{array}$ & $\begin{array}{l}3(75 \%) \\
{[65,66,68]}\end{array}$ \\
\hline \multicolumn{3}{|l|}{ SCHOOLS } \\
\hline Capability & $\begin{array}{l}5 \\
{[40,73,82,84,90]}\end{array}$ & $\begin{array}{l}4(80 \%) \\
{[40,73,82,84]}\end{array}$ \\
\hline Capability - Capacity to Plan & $\begin{array}{l}3 \\
{[40,82,90]}\end{array}$ & $\begin{array}{l}2(67 \%) \\
{[40,82]}\end{array}$ \\
\hline $\begin{array}{l}\text { Capability - Enhance Knowledge } \\
\text { and Skills of Individual }\end{array}$ & $\begin{array}{l}5 \\
{[40,73,82,84,90]}\end{array}$ & $\begin{array}{l}4(80 \%) \\
{[40,73,82,84]}\end{array}$ \\
\hline \multicolumn{3}{|l|}{ TARGET POPULATION } \\
\hline \multicolumn{3}{|l|}{ SECONDARY PREVENTION } \\
\hline Capability - Capacity to Plan & $\begin{array}{l}15 \\
{[60,63,71,72,78,80,83,86-88,92,93,99,103 \text {, }} \\
104]\end{array}$ & $\begin{array}{l}6(40 \%) \\
{[71,72,78,83,103,104]}\end{array}$ \\
\hline Capability - Empowerment & $\begin{array}{l}5 \\
{[67,71,92,94,99]}\end{array}$ & $\begin{array}{l}2(40 \%) \\
{[67,71]}\end{array}$ \\
\hline \multicolumn{3}{|l|}{ PROFESSION } \\
\hline \multicolumn{3}{|l|}{ MULTI-DISCIPLINARY TEAM } \\
\hline Capability - Capacity to Plan & $\begin{array}{l}10 \\
{[40,57,72,76-79,99,103,104]}\end{array}$ & $\begin{array}{l}7(70 \%) \\
{[40,72,76-78,103,104]}\end{array}$ \\
\hline $\begin{array}{l}\text { Capability - Enhance Knowledge } \\
\text { and Skills of Individual }\end{array}$ & $\begin{array}{l}13 \\
{[40,57,61,62,70,72,76-79,89,103,104]}\end{array}$ & $\begin{array}{l}8(62 \%) \\
{[40,70,72,76-78,103,104]}\end{array}$ \\
\hline \multicolumn{3}{|c|}{ TYPE OF MODIFIABLE RISK BEHAVIOURS INTERVENTION ADDRESSED ${ }^{\text {b }}$} \\
\hline \multicolumn{3}{|l|}{ ALCOHOL } \\
\hline $\begin{array}{l}\text { Capability - Beliefs about } \\
\text { Interventions }\end{array}$ & $\begin{array}{l}3 \\
{[71,89,90]}\end{array}$ & $\begin{array}{l}1(33 \%) \\
{[71]}\end{array}$ \\
\hline Capability - Empowerment & $\begin{array}{l}5 \\
{[65,71,75,90,94]}\end{array}$ & $\begin{array}{l}3(60 \%) \\
{[65,71,75]}\end{array}$ \\
\hline \multicolumn{3}{|l|}{ DIET } \\
\hline $\begin{array}{l}\text { Capability - Beliefs about } \\
\text { Interventions }\end{array}$ & $\begin{array}{l}4 \\
{[64,71,89,90]}\end{array}$ & $\begin{array}{l}1(25 \%) \\
{[71]}\end{array}$ \\
\hline \multicolumn{3}{|l|}{ PHYSICAL ACTIVITY } \\
\hline $\begin{array}{l}\text { Capability - Beliefs about } \\
\text { Interventions }\end{array}$ & $\begin{array}{l}4 \\
{[64,71,89,90]}\end{array}$ & $\begin{array}{l}1(25 \%) \\
{[71]}\end{array}$ \\
\hline \multicolumn{3}{|l|}{ STRESS } \\
\hline Capability - Capacity to Plan & $\begin{array}{l}10 \\
{[40,60,65,66,68,75,83,87,96,97]}\end{array}$ & $\begin{array}{l}6(60 \%) \\
{[40,65,66,68,75,83]}\end{array}$ \\
\hline Capability - Empowerment & $\begin{array}{l}3 \\
{[65,75,97]} \\
\end{array}$ & $\begin{array}{l}2(67 \%) \\
{[65,75]}\end{array}$ \\
\hline \multicolumn{3}{|c|}{ NUMBER OF MODIFIABLE RISK BEHAVIOURS } \\
\hline \multicolumn{3}{|l|}{3 BEHAVIOURS } \\
\hline Capability - Capacity to Plan & 19 & $\begin{array}{l}6(32 \%) \\
{[72,74,77,78,102,103]}\end{array}$ \\
\hline
\end{tabular}




\begin{tabular}{|c|c|c|}
\hline & $\begin{array}{l}{[12,57,64,72,74,77-80,86,88,92,93,95,96,} \\
99,100,102,103]\end{array}$ & \\
\hline Capability - Empowerment & $\begin{array}{l}7 \\
{[67,74,79,92,94,95,99]}\end{array}$ & $\begin{array}{l}2(29 \%) \\
{[67,74]}\end{array}$ \\
\hline \multicolumn{3}{|l|}{4 BEHAVIOURS } \\
\hline $\begin{array}{l}\text { Capability - Beliefs about } \\
\text { Intervention }\end{array}$ & $\begin{array}{l}3 \\
{[71,89,90]}\end{array}$ & $\begin{array}{l}1(33 \%) \\
{[71]}\end{array}$ \\
\hline \multicolumn{3}{|l|}{5 BEHAVIOURS } \\
\hline Capability & $\begin{array}{l}7 \\
{[59,60,65,75,87,91,97]}\end{array}$ & $\begin{array}{l}2(29 \%) \\
{[65,75]}\end{array}$ \\
\hline Capability - Capacity to Plan & $\begin{array}{l}5 \\
{[60,65,75,87,97]}\end{array}$ & $\begin{array}{l}2(40 \%) \\
{[65,75]}\end{array}$ \\
\hline Capability - Empowerment & $\begin{array}{l}3 \\
{[65,75,97]}\end{array}$ & $\begin{array}{l}2(67 \%) \\
{[65,75]}\end{array}$ \\
\hline $\begin{array}{l}\text { Capability - Enhance Knowledge } \\
\text { and Skills of Individual }\end{array}$ & $\begin{array}{l}6 \\
{[59,60,75,87,91,97]}\end{array}$ & $\begin{array}{l}1(17 \%) \\
{[75]}\end{array}$ \\
\hline
\end{tabular}

a The mechanisms within these interventions may not be exclusively for addressing smoking behaviour. It could be part of the overall intervention or for other risk behaviours within that intervention.

$\mathrm{b}$ This category examines interventions that include the specific risk behaviour (i.e. alcohol) as one of the targeted behaviours.

\section{Figures}




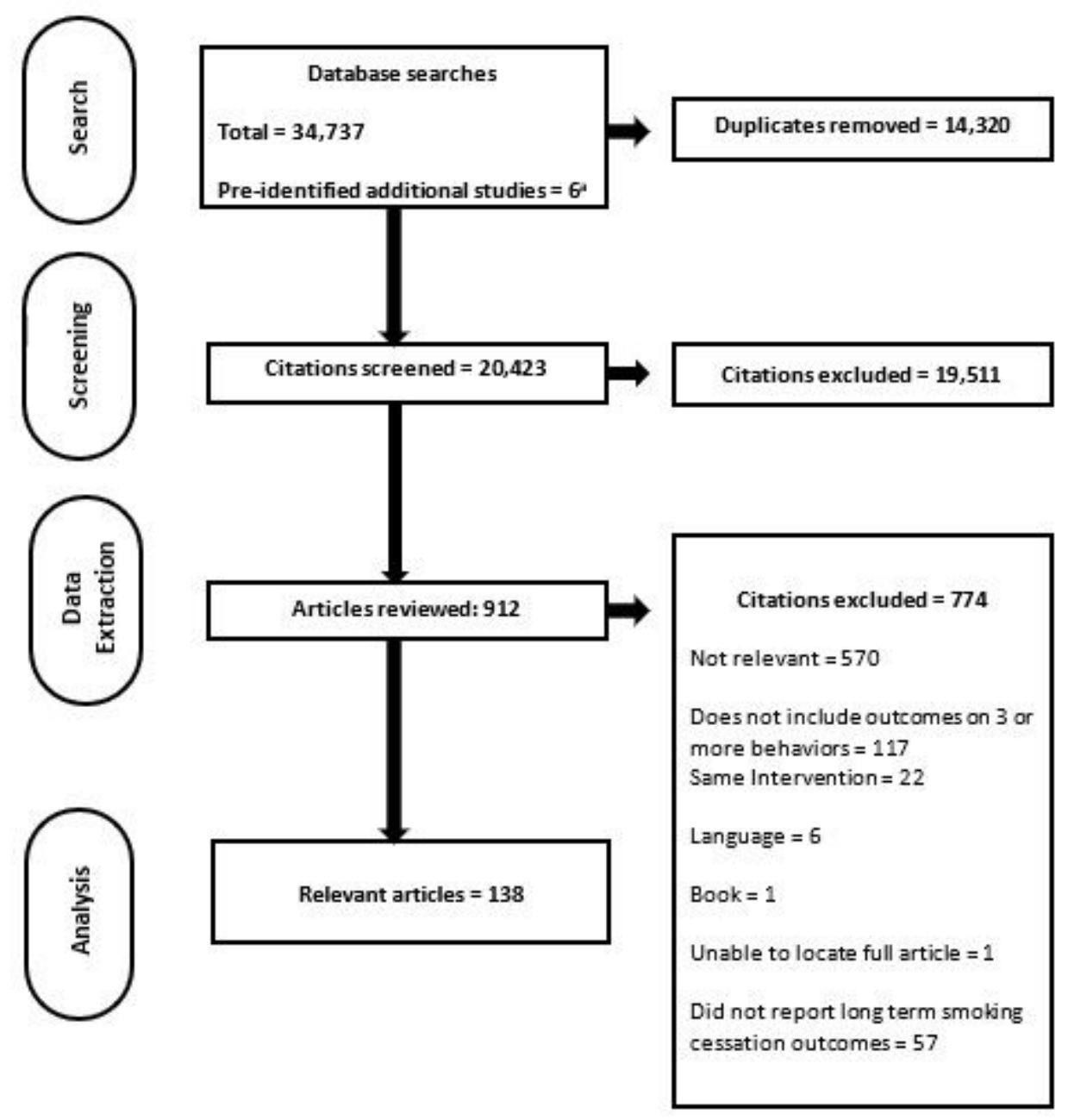

Figure 1

PRISMA flow diagram of articles through the rapid realist review process. aThere were a total of seven studies that were pre-identified for theory development; however one of the seven studies was published in 2013; which is within the timeframe for the literature search (2005 - 2017) and thus counted in this flow diagram as a part of the total number of studies from the literature search.

\section{Supplementary Files}

This is a list of supplementary files associated with this preprint. Click to download.

- AdditionalFile1.pdf

- 2.1.1PRISMA2009ChecklistFillable.doc

- AdditionalFile2.docx

- AdditionalFile3.docx 